\title{
Shared technology Transfer Program (STTP)
}

February 1, 2004-November 30, 2007

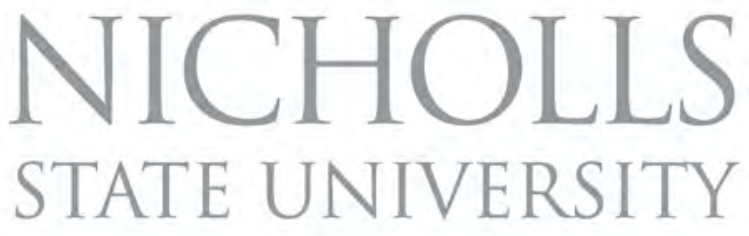

\section{Final Report}

Prepared by:

John M. Griffin, Ph.D., P.E.

NICHOLLS STATE UNIVERSITY

P O Box 2148

Thibodaux, Louisiana 70310 


\section{THE PROGRAM}

The overarching goal of Shared technology Transfer Program is to establish a collaborative process with domestic industries for the purpose of sharing Navy-developed technology. The purpose is to educate private business sectors to increase the awareness of these businesses to the vast amount of technologies that are available, with an initial focus on technology applications that are related to the Hydrogen, Fuel Cells and Infrastructure Technologies (Hydrogen) Program of the U.S. Department of Energy (DoE).

Specifically, the project is working to increase the industry awareness of the vast technology resources available to them that have been developed with taxpayer funding. Naval Sea Systems Command (NAVSEA)-Carderock and the Houston Advanced Research Center are teaming with Nicholls State University to catalog NAVSEA-Carderock unclassified technologies, rating the level of readiness of the technologies and establish a web based catalog of the technologies. In particular, the catalog contains technology descriptions, including testing summaries and overviews of related presentations, an April 30, 2005 evaluation of the technology readiness, and other information on the following fields of interest related to hydrogen technologies.

Background:

Over 600 Navy patents are available for technology transfer to several industries. Examples of particular interest to the Hydrogen Program include: hydrogen extraction from seawater (production), methane hydrate processing (production), carbon sequestration (production related), extremely high pressure valves and seals (storage), sensors and monitoring systems (storage and/or safety), and advanced power sources such as fuel cells for marine application. Others that may be hydrogen related are yet to be identified.

Primary organizations involved in the Shared technology Transfer Program include Nicholls State University, the Houston Advanced Research Center (HARC), South Louisiana Economic Council's Advanced Technology Center and the Naval Sea Systems Command Carderock Division (Carderock).

In FY-2004, the Shared technology Transfer Program target audience embraced southern domestic industries and university educators.

\section{Objectives were:}

1) Catalog NAVSEA-Carderock Unclassified Technologies with a focus on identifying those technologies that relate to the Department of Energy's (DoE) Hydrogen Program

- Maintain liaison with NAVSEA-Carderock

- Review and catalog NAVSEA-Carderock Unclassified Technologies - prepare briefings of technologies using catalog template

2) Rate the level of readiness for each hydrogen program-related technology

- Review briefings and rate level of technology readiness

- Decide on applicability to hydrogen program

3) Develop and implement an Educational Outreach program to increase awareness within hydrogenrelated industries

- Maintain liaison and coordinate potential industry sponsors

- Develop and implement plan to inform industry

4) Identify \& match hydrogen-related businesses that might benefit from the technologies 
- Identify and match companies that might benefit - meet with companies

- Recruit industry sponsors

- Assist industry with transfer of technologies

- Prepare plans to develop case studies w/industry for evaluation of transfer

- Perform case study

5) Launch an Educational Technology Showcase and website, featuring the initial set of technologies identified as being hydrogen related.

- Plan and hold technology showcase at NAVSEA-Carderock facility

- Complete and maintain webpage for Shared technology Transfer Program

6) Reporting and Briefings to DoE

- Maintain liaison and coordination with DoE

- Document results

- Attend appropriate meetings/conferences

- Identify approach for project to become self-sustaining

Program objectives were accomplished by these deliverables:

1. Catalog NAVSEA-Carderock Unclassified Technologies with a focus on identifying those technologies that relate to the Department of Energy's (DoE) Hydrogen Program

- Maintain liaison with NAVSEA-Carderock

- Review and catalog NAVSEA-Carderock Unclassified Technologies - prepare briefings of technologies using catalog template

\begin{tabular}{|c|c|l|c|}
\hline Date & $\begin{array}{c}\text { Objective } \\
\text { Number }\end{array}$ & \multicolumn{1}{|c|}{ Item } & Appendix \\
\hline $5 / 23 / 05$ & 1 & Bethesda, MD Catalog & \\
\hline $10 / 18 / 06$ & 1 & $\begin{array}{l}\text { Added a new catalog entry concerning the Navy's maintenance procedures has } \\
\text { been added: } \\
\text { http://www.harc.edu/Projects/BlueWater/Catalog/Technology?technologyID= } \\
807 \text { This includes the Navy's Joint Fleet Maintenance Manual, almost } 600 \\
\text { pages. It is organized in a pdf document that can be navigated. of interest could } \\
\text { be Chapter 1 on hull cleaning, Chapter 13 on corrosion control, and others. }\end{array}$ & \\
\hline $9 / 20 / 05$ & 1 & Houston-Sponsor meeting: Catalog entries & \\
\hline $4 / 12-15 / 05$ & 1 & Visited NAVSEA technologies at their site for determination of catalog entries & \\
\hline
\end{tabular}

\section{Rate the level of readiness for each hydrogen program-related technology}

- Review briefings and rate level of technology readiness

- Decide on applicability to hydrogen program

\begin{tabular}{|c|c|l|c|}
\hline Date & $\begin{array}{c}\text { Objective } \\
\text { Number }\end{array}$ & \multicolumn{1}{|c|}{ Item } & Appendix \\
\hline $7 / 31 / 05$ & 2 & Website populated with over 700 patents. & G \\
\hline $7 / 31 / 05$ & 2 & $\begin{array}{l}\text { An average of 127 unique visitors per month now visiting website. Each } \\
\text { patent was a assigned a Technology Readiness Level (TRL). }\end{array}$ & I \\
\hline
\end{tabular}




\section{Develop and implement an Educational Outreach program to increase awareness within hydrogen-related industries}

- Maintain liaison and coordinate potential industry sponsors

- Develop and implement plan to inform industry

\begin{tabular}{|c|c|c|c|}
\hline Date & $\begin{array}{l}\text { Objective } \\
\text { Number }\end{array}$ & Item & Appendix \\
\hline $3 / 1 / 03$ & 3 & $\begin{array}{l}\text { Pre-publicity for Houston Advanced Research Center NAVSEA-Caderock } \\
\text { technology transfer initiative, Offshore, March 2003, } 20 .\end{array}$ & $\mathrm{E}$ \\
\hline $1 / 13 / 05$ & 3 & $\begin{array}{l}\text { Houston-Held workshop to present Navy technologies to industry. Twelve } \\
\text { companies attended. }\end{array}$ & \\
\hline $1 / 31 / 05$ & 3 & Developed presentation of 24 slides describing this research initiative & \\
\hline $3 / 31 / 05$ & 3 & $\begin{array}{l}\text { Made presentation and distributed program information at Texas A \& M } \\
\text { University }\end{array}$ & \\
\hline $4 / 19 / 05 \mathrm{a}$ & 3 & $\begin{array}{l}\text { Made presentation to } 122 \text { personnel affiliated with South Central Industrial } \\
\text { Association, Houma, LA describing this research initiative. }\end{array}$ & \\
\hline $4 / 19 / 05$ & 3 & Published brochure for disseminating technologies & $\mathrm{F}$ \\
\hline $4 / 27 / 05$ & 3 & $\begin{array}{l}\text { Conducted radio interviews on multiple stations for disseminating technologies } \\
\text { (4/27-statewide in Louisiana; 5/4-Houma,LA; 5/8-Houma, LA) }\end{array}$ & \\
\hline $4 / 27 / 05$ & 3 & $\begin{array}{l}\text { Performed radio interview for broadcast statewide for "Louisiana Live," a } \\
\text { radio talk show about happenings across the state, (800) 673-5555. } \\
\text { Interviewed at 2:35 P.M. Wednesday, April 27. Don Grady, host interviewed } \\
\text { Dr. Griffin on the Shared Technology Transfer program. }\end{array}$ & \\
\hline $4 / 21 / 05$ & 3 & $\begin{array}{l}\text { Presented program to meeting of Gulf States Petroleum Exhibition \& } \\
\text { Conference (energy companies of New Orleans) in New Orleans. }\end{array}$ & G \\
\hline $4 / 19 / 95$ & 3 & Published press releases for disseminating technologies & $\mathrm{H}$ \\
\hline $5 / 4 / 05$ & 3 & $\begin{array}{l}\text { Performed radio interview May } 4 \text { for public service and same was broadcasted } \\
\text { Sunday May 8th KGIN 1490AM @6-7 am; 96.7FM @ 7-8 am; 106.3FM @ 8- } \\
\text { 9a.m., } 107.5 \text { @9-10 am. Station is owned/operated by Guaranty broadcasting } \\
\text { of Houma, LA. }\end{array}$ & \\
\hline $5 / 2-5 / 05$ & 3 & $\begin{array}{l}\text { Distributed program information at the NAVSEA and DoE booths at } \\
\text { Houston's annual Oil Technology Conference (OTC). }\end{array}$ & \\
\hline $7 / 26 / 05$ & 3 & $\begin{array}{l}\text { Dr. Griffin visited office of Congressman Charlie Melancon, La. } 3^{\text {rd }} \text { District, to } \\
\text { familiarize congressman with Shared Technology Transfer Program. }\end{array}$ & \\
\hline $7 / 31 / 05$ & 3 & $\begin{array}{l}\text { Began dialogue with second trade association, the South Louisiana Economic } \\
\text { Council (SLEC). }\end{array}$ & \\
\hline $12 / 16 / 05$ & 3 & $\begin{array}{l}\text { Houston-Research Partnership to Secure Energy for America (RPSEA) } \\
<\text { http://www.rpsea.org/ > meeting (non-profit national consortium). }\end{array}$ & \\
\hline $1 / 13 / 06$ & 3 & $\begin{array}{l}\text { Houston-workshop to present various Navy technologies to industry. Twelve } \\
\text { (12) separate companies were in attendance. }\end{array}$ & \\
\hline $3 / 15 / 06$ & 3 & $\begin{array}{l}\text { Houston-Speaker: Canadian Environmental Solutions for the Energy Industry } \\
<\text { http://www.ic.gc.ca/epic/site/ces-sec.nsf/en/Home }>\end{array}$ & \\
\hline $3 / 20 / 06$ & 3 & $\begin{array}{l}\text { Houston-Site visit to GPM, Inc. to discuss Shared technology Transfer } \\
\text { Program. }\end{array}$ & \\
\hline $3 / 21 / 2006$ & 3 & Houston-Sponsor meeting: Corrosion Control & \\
\hline $3 / 23-25 / 06$ & 3 & $\begin{array}{l}\text { Students attended National Collegiate Inventors and Innovators Alliance } \\
\text { (NCIIA) }<\text { http://www.nciia.org/ }>\text { in Portland, OR where technology } \\
\text { transfer was studied; results presented in workshop on 5/15/06, see below. }\end{array}$ & \\
\hline $3 / 24 / 06$ & 3 & $\begin{array}{l}\text { College Station at Texas A\&M Shared technology Transfer Program } \\
\text { presentation. }\end{array}$ & \\
\hline $4 / 21 / 06$ & 3 & New Orleans, LA Speaker "Transition into the Hydrogen economy" & \\
\hline $4 / 24 / 06$ & 3 & Thibodaux, LA Shared technology Transfer Program Review and workshop & \\
\hline $4 / 26 / 06$ & 3 & Houston ExxonMobil presentation of Shared Technology Transfer Program & \\
\hline $5 / 15 / 06$ & 3 & $\begin{array}{l}\text { Held workshop at Nicholls State University with student presenters and } \\
\text { attended by local companies and the district's U.S. congressman. Engaged } \\
\text { services of the (SLEC) < http://www.slec.org/site.php > in Houma, LA who } \\
\text { orchestrated an educational session highlighting NAVSEA technologies for } \\
\text { area industry. The project was student led as each student thoroughly reviewed }\end{array}$ & $\mathrm{A}$ \\
\hline
\end{tabular}




\begin{tabular}{|c|c|c|c|}
\hline & & $\begin{array}{l}\text { his/her selected technology and presented same. Student presenters were: } \\
\text { Tobie Benoit, Andrew Gaiennie, Jamie Hodge, Kevin Morales, Scott Oliver, } \\
\text { Monique Robbins, and Candy Sikes. Attendees included: members from the } \\
\text { Port Of New Orleans, members from the Port of Morgan City, member from } \\
\text { the Port of Fourchon, Louisiana, members from Oi1 States Industries: Inc., } \\
\text { member from The Shaw Group, member from T. Baker Smith, member from } \\
\text { Bollinger Shipyards, the Honorable Congressman Charlie Melancon of } \\
\text { Louisiana, Nicholls State University faculty Drs. Tom Bryant and John Griffin, } \\
\text { Research Scientist Dr. Richard Haut of the Houston Advanced Research } \\
\text { Center, Vic Lafont and SLEC'S Public Affairs Director Mr. Charles Gaiennie. } \\
\text { It was to educate and inform key maritime and port officials of benefits of the } \\
\text { Bilge and Oily Waste Water System, Advanced Crane System, Underwater } \\
\text { Hull Husbandry Robot, Non-Destructive Evaluation and the Twisted Rudder } \\
\text { benefits. }\end{array}$ & \\
\hline $4 / 15 / 07$ & 3 & $\begin{array}{l}\text { Panama, Central America. April 15-19 Attended Louisiana District Export } \\
\text { Council,< http://www.ldec.org/ > in conjunction with Louisiana Economic } \\
\text { Development, the U.S. Commercial Service, the Port of New Orleans and the } \\
\text { City of New Orleans a trade mission to the country of Panama. The purpose of } \\
\text { mission was to promote Louisiana's trade, transportation, Louisiana as a } \\
\text { destination for international investments, tourism and other reciprocal interests } \\
\text { with Panama. This outreach provided a vehicle to showcase maritime patents } \\
\text { from the U.S. Navy technology database including hydrogen fuels } \\
\text { technologies. The expansion of the canal will spend over } \$ 5 \text { billion. }\end{array}$ & $\mathrm{D}$ \\
\hline $3 / 9 / 07$ & 3 & $\begin{array}{l}\text { Discussed Blue Water Technology Consortium < } \\
\text { http://www.harc.edu/Projects/BlueWater/ > at meeting with the Research } \\
\text { Partnership to Secure Energy for America (RPSEA). }\end{array}$ & \\
\hline $4 / 12 / 07$ & 3 & $\begin{array}{l}\text { Discussed Blue Water Technology Consortium with potential new consortium } \\
\text { member. }\end{array}$ & \\
\hline
\end{tabular}

\section{Identify \& match hydrogen-related businesses that might benefit from the technologies}

- Identify and match companies that might benefit - meet with companies

- Recruit industry sponsors

- Assist industry with transfer of technologies

- Prepare plans to develop case studies w/industry for evaluation of transfer

- Perform case study

\begin{tabular}{|c|c|l|c|}
\hline Date & $\begin{array}{c}\text { Objective } \\
\text { Number }\end{array}$ & \multicolumn{1}{|c|}{ Item } & Appendix \\
\hline $1 / 31 / 05$ & 4 & $\begin{array}{l}\text { Identify partner in South Central Industrial Association; Met with these } \\
\text { members; Formulated plans for contacting local industry }\end{array}$ & \\
\hline $5 / 11-12 / 05$ & 4 & Norfolk, VA Live full-scale crane demonstration for industry representatives & \\
\hline $5 / 19 / 05$ & 4 & $\begin{array}{l}\text { Houston - Sponsor meeting: Hull Inspection/Environmentally Friendly } \\
\text { Drilling systems }\end{array}$ & \\
\hline $6 / 14 / 05$ & 4 & Houston-Noble Drilling Services Inc. Potential projects meeting & \\
\hline $7 / 31 / 05$ & 4 & $\begin{array}{l}\text { Followed up with industry contact following Griffin's 4/19/05 presentation to } \\
\text { local industry representatives in Houma, LA }\end{array}$ & \\
\hline
\end{tabular}

While no patents have, as yet, been licensed, there have been several technology exchanges. Beyond rating of technology readiness (TRL), several technologies have received in-depth analysis and described by case histories or case studies. These are enumerated here with associated links:

\begin{tabular}{|l|l|}
\hline \multicolumn{1}{|c|}{ Technology } & \multicolumn{1}{c|}{ Web Link } \\
\hline $\begin{array}{l}\text { Wastewater } \\
\text { Treatment/Separators }\end{array}$ & http://www.harc.edu/Projects/BlueWater/About/ProgramSummary \\
\hline $\begin{array}{l}\text { Submarine outboard } \\
\text { equipment grease and external } \\
\text { hydraulics discharge summary }\end{array}$ & http://www.harc.edu/Projects/BlueWater/About/ProgramSummary \\
\hline
\end{tabular}




\begin{tabular}{|l|l|}
\hline $\begin{array}{l}\text { Hull maintenance and } \\
\text { inspection }\end{array}$ & $\underline{\text { http://www.harc.edu/Projects/BlueWater/About/ProgramSummary }}$ \\
\hline $\begin{array}{l}\text { Electric motor thruster } \\
\text { preliminary designs }\end{array}$ & Not available. \\
\hline $\begin{array}{l}\text { Coating systems for aluminum } \\
\text { underwater hull surfaces }\end{array}$ & $\underline{\text { http://www.harc.edu/Projects/BlueWater/About/ProgramSummary }}$ \\
\hline $\begin{array}{l}\text { Weldable marine grade } \\
\text { aluminum allows paint/coating } \\
\text { systems for maritime appli- } \\
\text { cations }\end{array}$ & $\underline{\text { http://www.harc.edu/Projects/BlueWater/About/ProgramSummary }}$ \\
\hline
\end{tabular}

\section{Launch an Educational Technology Showcase and website, featuring the initial set of technologies identified as being hydrogen related.}

- Plan and hold technology showcase at NAVSEA-Carderock facility

- Complete and maintain webpage for Shared technology Transfer Program

\begin{tabular}{|c|c|l|c|}
\hline Date & $\begin{array}{c}\text { Objective } \\
\text { Number }\end{array}$ & \multicolumn{1}{|c|}{ Item } & Appendix \\
\hline $\begin{array}{c}\text { 9/14- } \\
15 / 2004\end{array}$ & 5 & $\begin{array}{l}\text { Held technology show case with over 30 member companies from industry, } \\
\text { overview of NAVSEA-Caderock technologies. }\end{array}$ & \\
\hline $1 / 31 / 05$ & 5 & $\begin{array}{l}\text { Developed prototype web site } \\
\text { http://www.nicholls.edu/sttp/ } \\
\text { http://www.sharedtechtransfer.org/ }\end{array}$ & \\
\hline $4 / 19 / 05$ & 5 & Launched website for disseminating technologies & \\
\hline $7 / 31 / 05$ & 5 & Website visited by 63 viewers May 1-June 13. & \\
\hline
\end{tabular}

Hydrogen related technologies were sought and identified among the 700 plus NAVSEA-Caderock technologies. They are listed below. The web address is:

$$
\text { < http://www.sharedtechtransfer.org/ShowCategory.aspx? categoryID=52 > }
$$

1. Concentration of Isotropic Hydrogen by Temperature Gradient Effect in Soluble Metal Isotopic hydrogen enrichment in a soluble metal is achieved through temperature gradient effects by applying a heat source and a heat sink to two spaced regions of the metal within which isotopic hydrogen atoms are absorbed and enclosed by a diffusion-barrier material. The temperature gradient so created forces the atoms of hydrogen in the hot region to migrate into the cold region, resulting in higher isotopic hydrogen density in the cold region. Discharge of the absorbed isotopic hydrogen is prevented effectively by the diffusion-barrier material.

2. Fuel Cell Laboratory

NAVSEA has a fuel cell laboratory that is devoted to the testing and evaluation for fuel cell power plants for naval surface and undersea applications. The laboratory is designed for testing up to 2.5 megawatts of power generated from fuel cells and for interconnection with nearby electrical or mechanical laboratories to form an integrated system. Dedicated computer-controlled instrumentation, including a gas chromatograph and on-line gas analyzers, and video recording equipment are available for testing fuel cells and fuel-reforming hardware.

3. Material and Method for Fast Generation of Hydrogen Gas and Steam

A high power pulse of electrical current causes a metal conductor to explode and initiate a reaction between an aluminum or aluminum alloy powder and water which generates hydrogen gas at a high temperature and pressure. The reaction mixture is released into a second larger chamber equipped with heat exchanger which extracts useful heat energy and cools down the reaction mixture. 
The hydrogen gas is then separated from the solid metal oxide byproducts in the cooled reaction mixture.

4. Electrolytic Disinfectant System

An electrolytic disinfectant system especially useful in a maritime application for treating freshwater so as to render it potable, provides a brine solution that is stored in a tank from which hypochlorite as the disinfectant is fed to a freshwater supply. Gases also fed to the disinfectant storage tank including hydrogen are discharged there from and passed to a hydrogen re-combiner through which the hydrogen is disposed of by reaction with oxygen under control of external heating bands to generate water vapor. The system thereby provides enhanced disinfectant effectiveness and eliminates storage of hazardous chemicals.

5. Fuel Cells

Fuel cells have been developed to increase the fuel efficiency and survivability of ships. The fuel cell technology is used in conjunction with gas turbine generators to more effectively distribute power and reduce fuel consumption. This results in a significant cost savings. In addition, fuel cell technology is quiet with low emissions. Examples of fuel cell technology include the Molten Carbonate Ship Service Fuel Cell System (MCFC) and the Proton Exchange Membrane (PEM) Ship Service Integrated Fuel Cell Processor. The MCFC is a $625 \mathrm{KW}$ system with a molten carbonate fuel cell for use with diesel inlet fuel. The PEM is a 500KW fuel processor with a simulated PEM fuel cell stack for use with diesel inlet fuel.

The Office of Naval Research spearheaded the development of fuel cell advancements to increase the overall efficiency of the Naval Fleet. Tests indicate that powering ships with both a fuel cell and gas turbine result in substantial fuel savings at speeds below 14 knots. This is significant because ships in the Naval Fleet spend approximately $85 \%$ of their time below 14 knots. Applications:

NAVSEA-Carderock currently has a program to demonstrate the use of fuel cells for maritime applications. TRL: 3

6. Method for Launching Projectiles with Hydrogen Gas

A method for propelling a projectile by applying a high power pulse of electrical current to a metal fuel element (of $\mathrm{Al}, \mathrm{Al}-\mathrm{Li}$, or $\mathrm{Al}-\mathrm{Mg}$ ) causing the element to explode dispersing molten metal fuel into water with which it reacts to rapidly generate hydrogen gas at high pressure; the hydrogen gas is used to push the projectile. After the peak current is reached, an inductive electrical energy source drives the electrical current into the molten metal fuel/water mixture thus driving the reaction to completion.

7. Explosive Containment Device

The inventive device includes a box-shaped steel shell and rigid polyurethane foam which partially occupies the shell's interior so as to leave a compartment to be used for situation of a suspected explosive object. The compartment is accessed by a doored entrance which is provided in the shell. Some inventive embodiments include a polyethylene liner for foam wear protection, and/or a high-strength layer for attenuating explosive fragmentation. Foam bodies are carefully packed inside the compartment for separating the suspected explosive device from the doored entrance and for stabilizing the suspected explosive object during transit. Upon detonation, the foam pulverizes and the shell inelastically deforms into an ovaloid or cylindroid shape. The shell's edges and corners are convexly contoured for thwarting localized strain concentrations in the shell. The inventive device is implemented for a single explosive event, as distinguished from conventional explosive containment devices which are implemented on a repetitive basis. As compared with conventional devices, typical inventive embodiments are small, lightweight, portable and inexpensive; yet, unlike conventional devices, the invention's doored entrance and compartment are dimensioned to accommodate a large suspect package in its entirety, thereby obviating disassembly of the package. 
8. High-Energy-Absorbing Enclosure for Internal Explosion Containment

A structural enclosure, box-like for many embodiments, which effectively contains an explosion, thereupon remaining virtually intact and minimizing fragmentation. The structural wall has a sandwich-like arrangement of two fiber-reinforced matrix material skins and a foam core situated between the two skins, at least one skin having fiber-reinforced high strain-to-failure viscoelastic matrix material. The core foam material selectively varies in density so as to provide appropriate rigidity or flexibility at different locations of the structural enclosure. The fiber-reinforced high strainto-failure viscoelastic matrix material can be deformed elastically to large strains, has demonstrably high energy-absorbing characteristics, and is relatively lightweight. Upon explosive impact, the inner skin largely deforms so as to be energy-absorbent of the pressure wave caused by the explosive charge, the foam core crushes so as to also be energy-absorbent, the outer skin largely deforms, and both skins contain debris.

9. Protective Device for Container

A protective device for a container containing toxic or hazardous materials includes a shell, a mechanism positioned in the shell for sealing a puncture in the container so as to prevent release of the toxic materials from the container and a mechanism for attaching the shell to the container.

\section{Reporting and Briefings to DoE}

- Maintain liaison and coordination with DoE

- Document results

- Attend appropriate meetings/conferences

- Identify approach for project to become self-sustaining

\begin{tabular}{|c|c|c|c|}
\hline Date & $\begin{array}{l}\text { Objective } \\
\text { Number }\end{array}$ & Item & Appendix \\
\hline $1 / 31 / 05$ & 6 & Met with managers of NAVSEA-Caderock & \\
\hline $5 / 25 / 05$ & 6 & Made progress report DoE in Alexandria, VA 4:45P.M. & \\
\hline \multirow[t]{2}{*}{$10 / 31 / 05$} & 6 & $\begin{array}{l}\text { Bryant, T.A., et al. (2005) "Commercialization of Big Government } \\
\text { Technology through SMEs: Design and Performance Metrics for the Shared } \\
\text { Technology Transfer Program," paper presented to the 19th Annual UIC } \\
\text { Research symposium on Marketing and Entrepreneurship; San Francisco; } \\
\text { August. }\end{array}$ & $\mathrm{C}$ \\
\hline & 6 & $\begin{array}{l}\text { http://www.hydrogen.energy.gov/pdfs/progress06/ix_7_griffin.pdf is the } 2005 \\
\text { annual report in public domain online }\end{array}$ & \\
\hline 9/6/06 & 6 & $\begin{array}{l}\text { Dr. Ronnie Fanguy of Nicholls State University performed web analysis on all } \\
\text { hits to the created website where Navy technologies can be viewed by the } \\
\text { public. Report included. }\end{array}$ & B \\
\hline $10 / 10 / 06$ & 6 & $\begin{array}{l}\text { Held Blue Water Technology Consortium meeting where NAVSEA Carderock } \\
\text { presented an overview of their computational fluid dynamics efforts and } \\
\text { hydrodynamic testing facilities. }\end{array}$ & \\
\hline $12 / 1 / 06$ & 6 & $\begin{array}{l}\text { Issued Blue Water Technology Consortium annual report summarizing } \\
\text { NAVSEA Carderock presentations and projects funded by the consortium. }\end{array}$ & \\
\hline $6 / 17 / 07$ & 6 & $\begin{array}{l}\text { Travel to Golden, CO to meet with DoE staff and clarify grant objectives and } \\
\text { reporting requirements. }\end{array}$ & \\
\hline
\end{tabular}




\section{Appendices}




\section{Appendix A}


(4) I (im in gुํํำ r

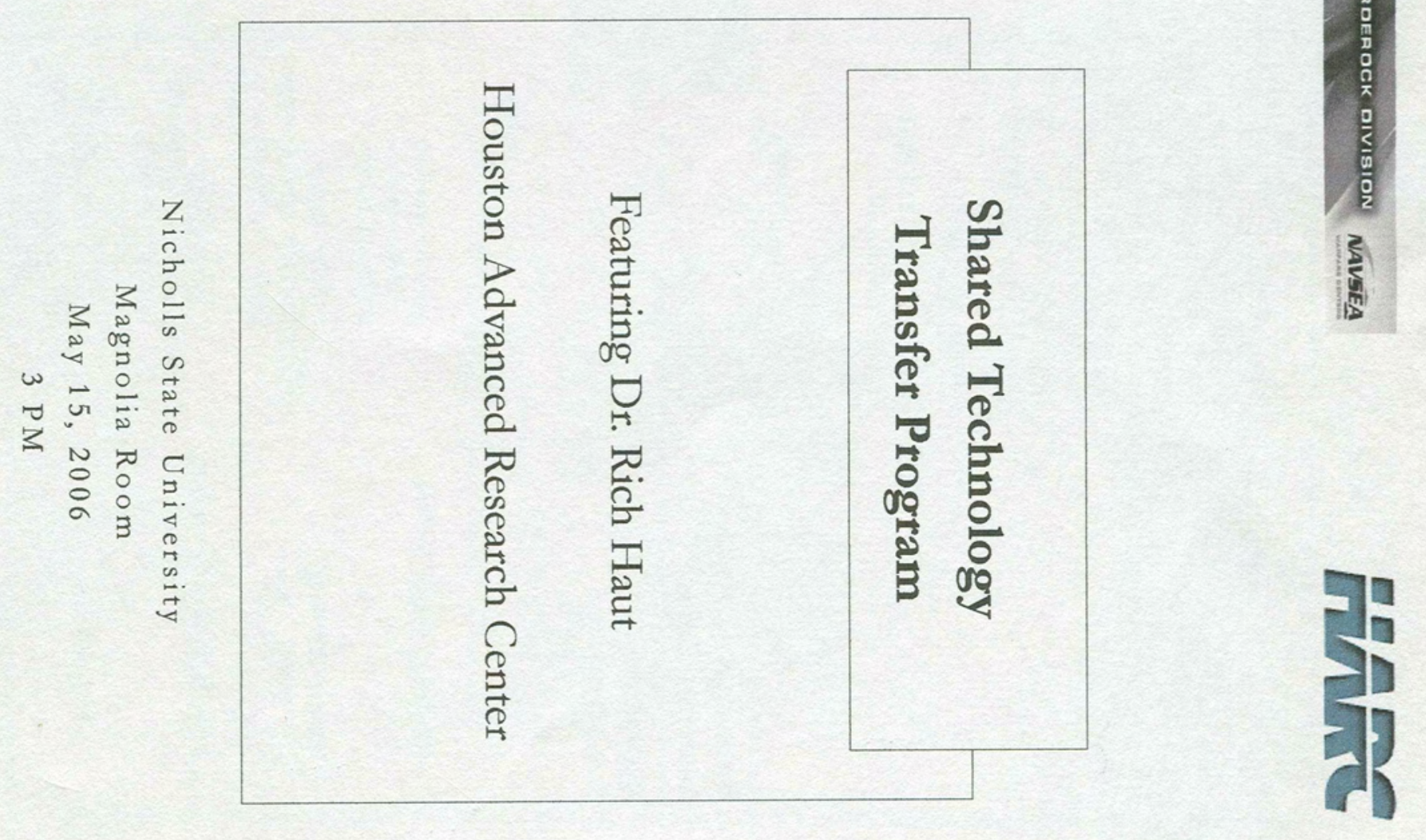


Quarterly Progress Report June 30, 2006

DE-FC36-04G014226

Engaged services of the South Louisiana Economic Council (SLEC) in Houma, LA and Ms. Anne Sonnier who orchestrated an educational session highlighting Navsea technologies for area industry. The project was student led as each student thoroughly reviewed each technology and presented same. Student presenters were: Tobie Benoit, Andrew Gaiennie, Jamie Hodge, Kevin Morales, Scott Olivier, Monique Robbins, and Candy Sikes.

Attendees included:

1. members from the Port of New Orleans,

2. members from the Port of Morgan City,

3. member from the Port of Fourchon, Louisiana,

4. members from Oil States Industries Inc.,

5. member from The Shaw Group,

6. member from T. Baker Smith,

7. member from Bollinger Shipyards,

8. the Honorable Congressman Charlie Melancon of the 3rd congressional district state of Louisiana,

9. Nicholls State University faculty Drs. Tom Bryant and

10. John Griffin, Research Scientist and

11. Dr. Richard Haut of the Houston Advanced Research Center,

12. Leader of student research initiative Ms. Anne Sonnier and

13. Director of SLEC, Mr. Vic Lafont and

14. SLEC'S Public Affairs Director Mr. Charles S. Gaiennie.

This showcase was held at Nicholls State University's Magnolia Room, Student Union on Monday, May 15. 2006. Its purpose was to educate and inform key maritime and port officials of benefits of the Bilge and Oily Waste Water System, Advanced Crane System, Underwater Hull Husbandry Robot, Non-destructive Evaluation, and the Twisted Rudder.

June 30, 2006_AnneSonnier 

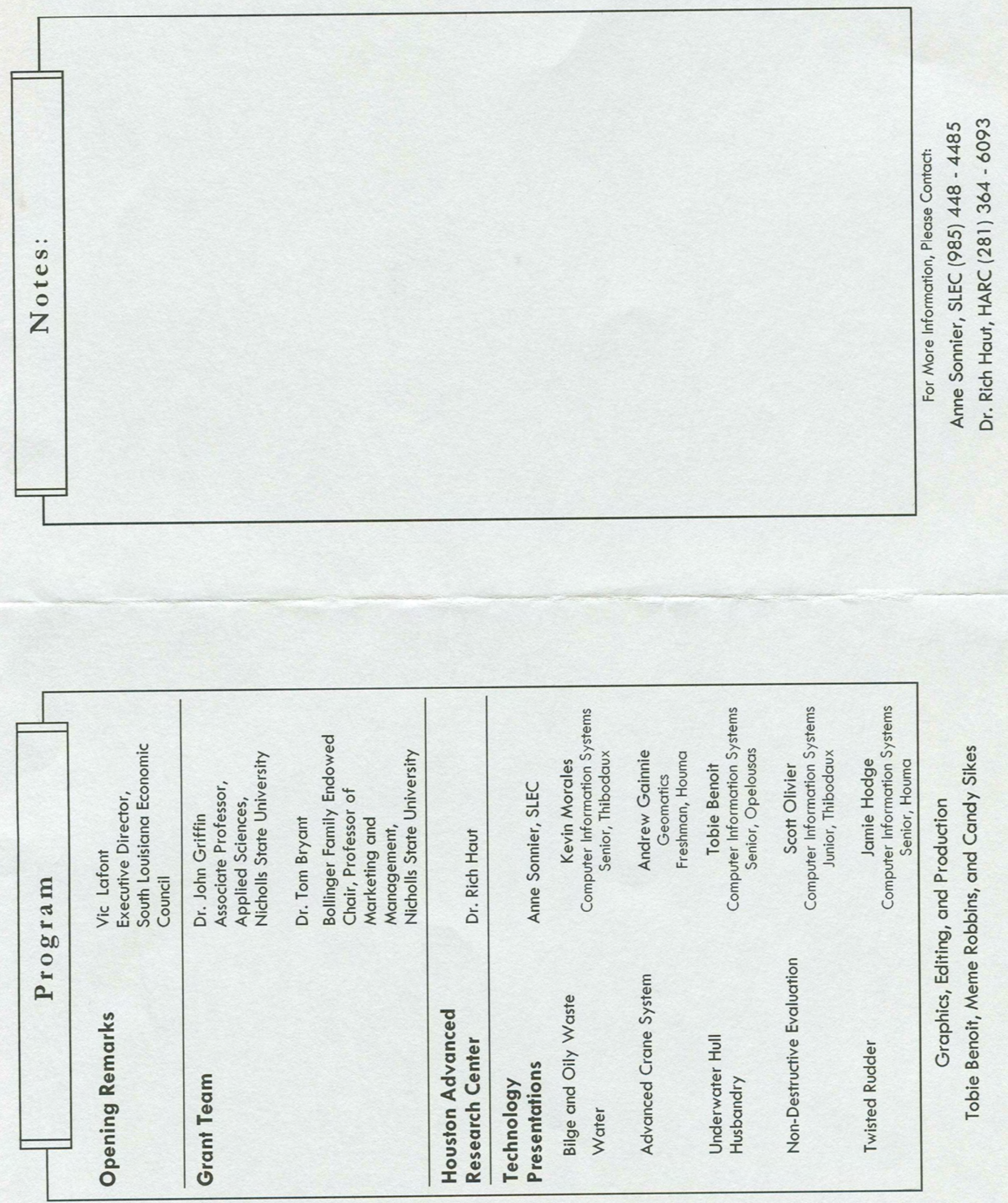


\section{Appendix B}




\title{
Shared Technology Transfer Project: A Report on the Web Site's Effectiveness
}

\author{
Dr. Ronnie Fanguy \\ Nicholls State University \\ September 9, 2007
}


Nicholls State University and the Houston Advanced Research Center worked together in 2005 and 2006 in an attempt to transfer technologies developed by and for the US Navy to the ship building industry. This report focuses on the web site that was designed and built to facilitate the transfer process. The primary purpose of the web system is to facilitate the sharing of information regarding the navy technologies that are available for licensing with those who may benefit from the technologies. The database of navy technologies and the web-based catalog enabling users to browse through the technologies was made available through the Houston Advanced Research Center (HARC). HARC, along with Nicholls State University (NSU), worked to make the potential beneficiaries of these navy technologies aware that they were available. A summary of the system's structure is depicted below.

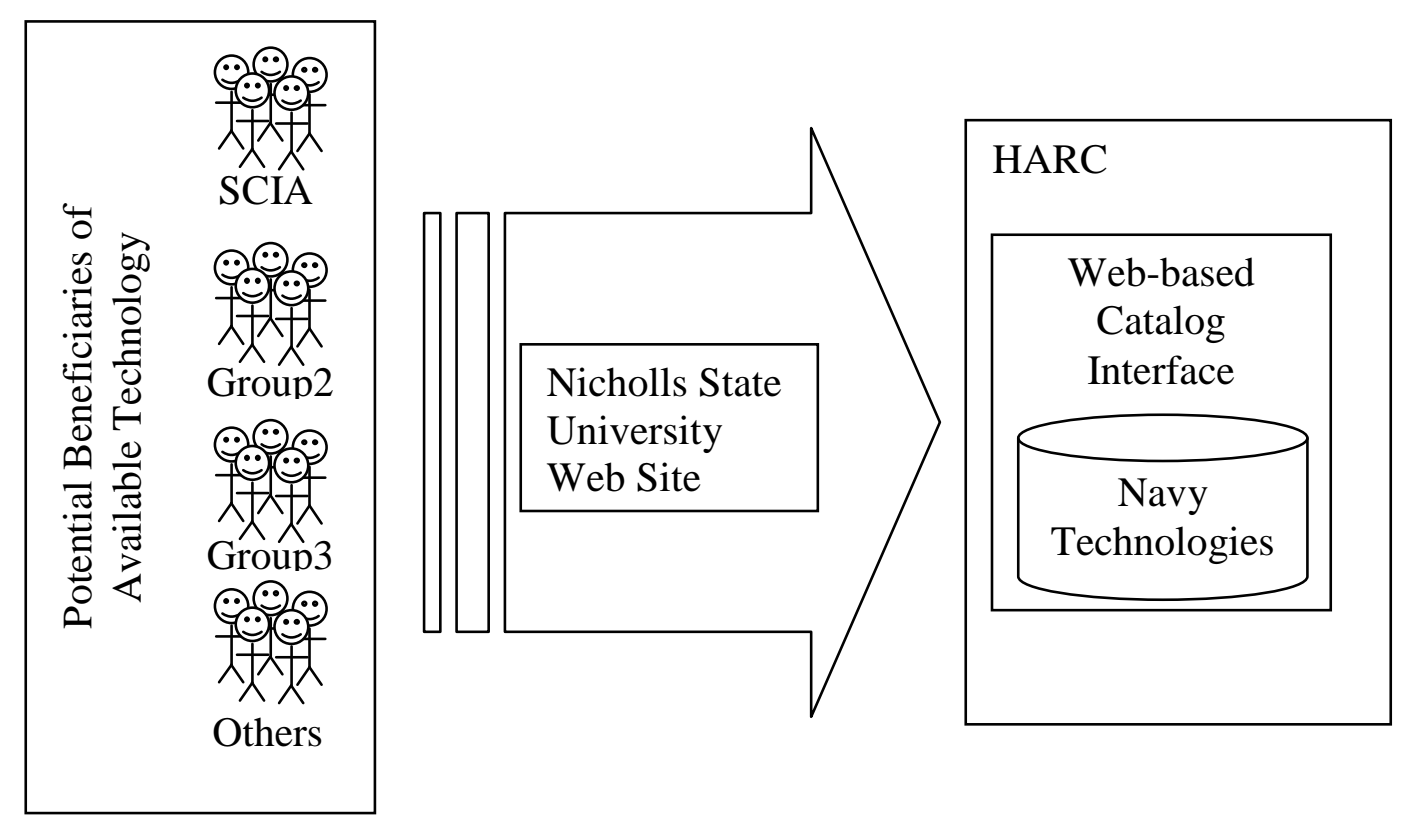

In the remainder of this paper, we summarize data gathered on the usage of the Webbased catalog that was hosted by HARC. Readers should note that the summary presented here deviates slightly from the analysis provided directly by HARC primarily because of the differences in identifying users to the web site. The data provided to the authors limited us to identifying users by the IP address assigned to their "hit" on HARC's web site.

We provide the following graphs:

- Visitors per Month

- How Many Times Visitors Accessed Web Site

- Number of Web Pages Viewed Per Visitor

- Number of Technologies Viewed Per Visitor

- Number of Categories Viewed Per Visitor 
- Monthly Web Site Access (Number of Pages, Technologies, Categories viewed per month)

- Pages Viewed Within 1 Week of Publicizing Events

- Timeline: Effect of Publicizing Events on Number of Visitors (7 Day Moving Average)

- Timeline: Effect of Publicizing Events on Number of Pages Viewed (7 Day Moving Average)

- Most Popular Technologies

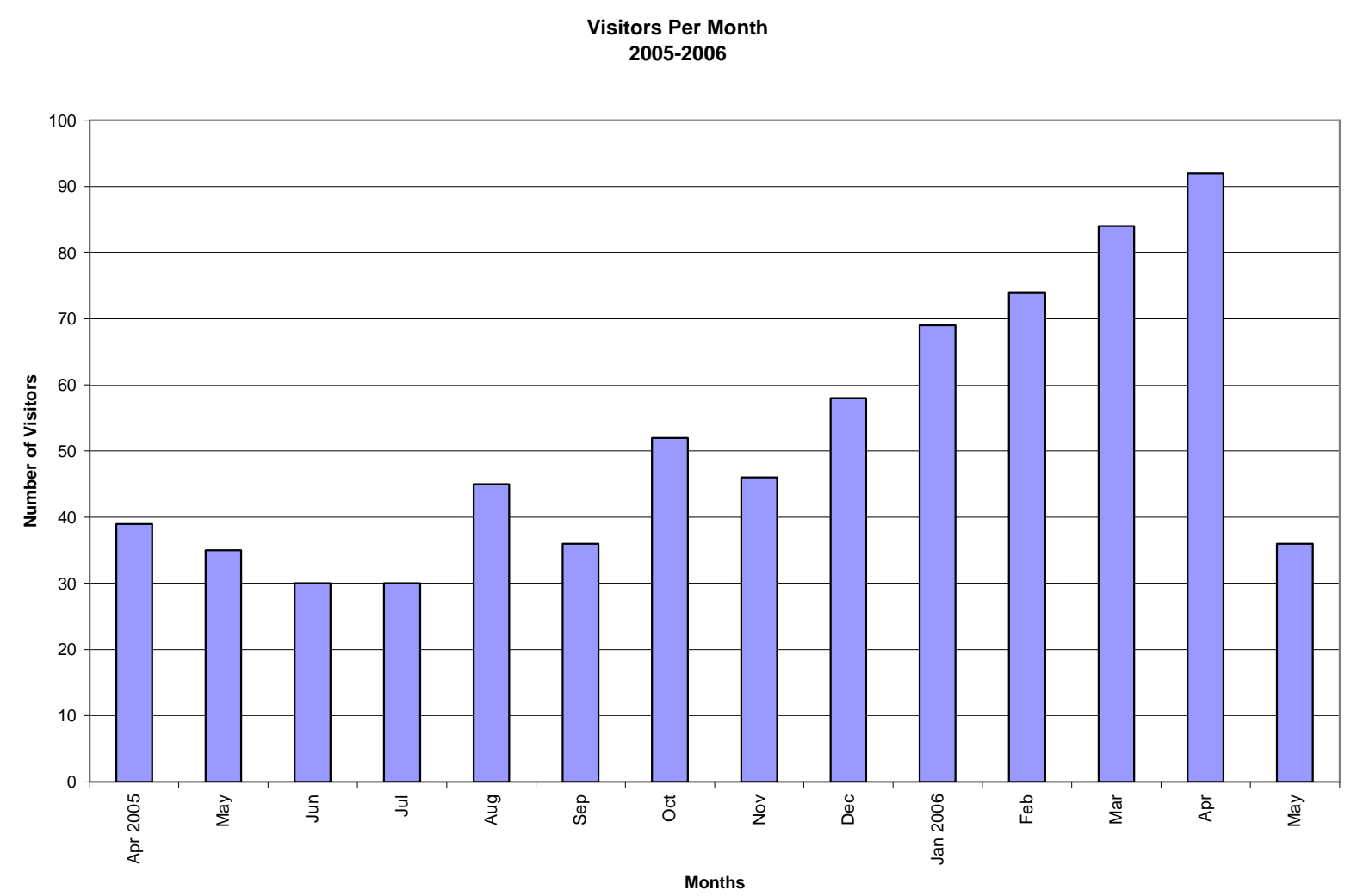

This graph shows how many unique IP addresses accessed the web site each month. Note that we only had data for 8 days in May 2006. 


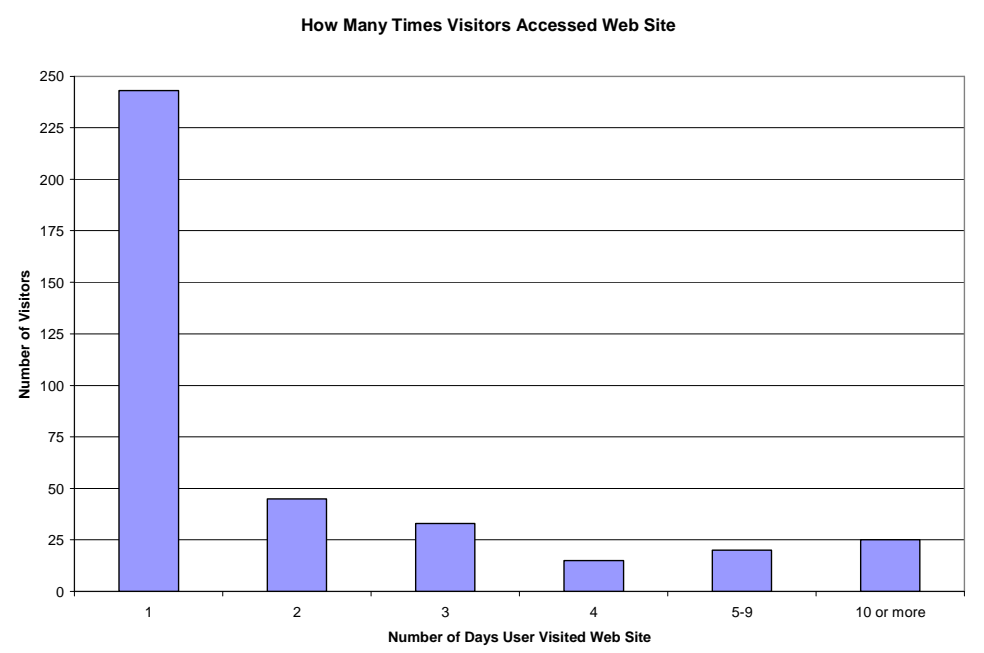

This graph depicts the user return rate-how many different days each user visited the web site. The overwhelming majority of users only visited once.

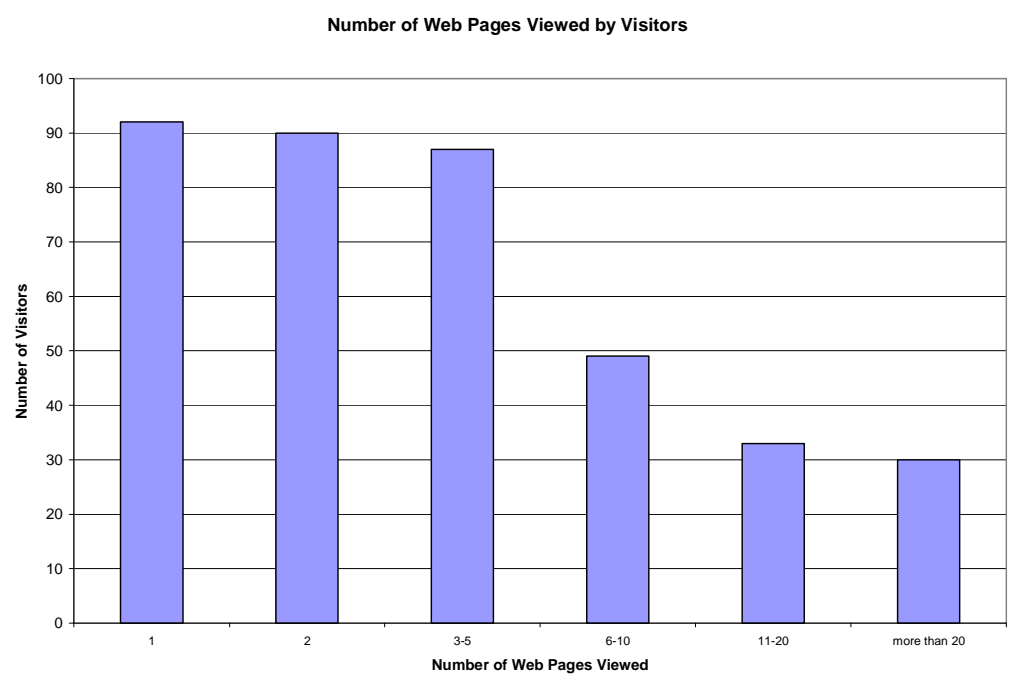

This graph shows how interested users were in our web site by graphing how many different web pages they viewed while they were visiting. By and large, users did not pull up many pages. 


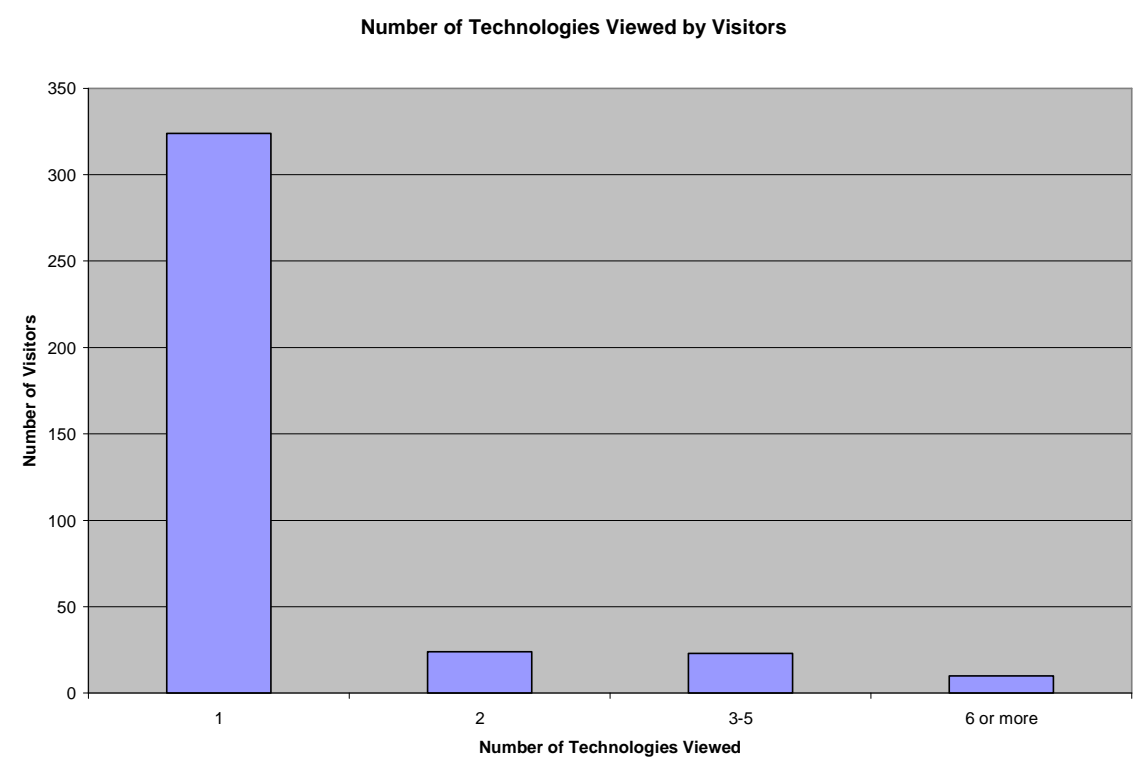

This graph shows how many technologies each user accessed. Almost no one pulled up more than 1 technology.

Categories Viewed by Visitors

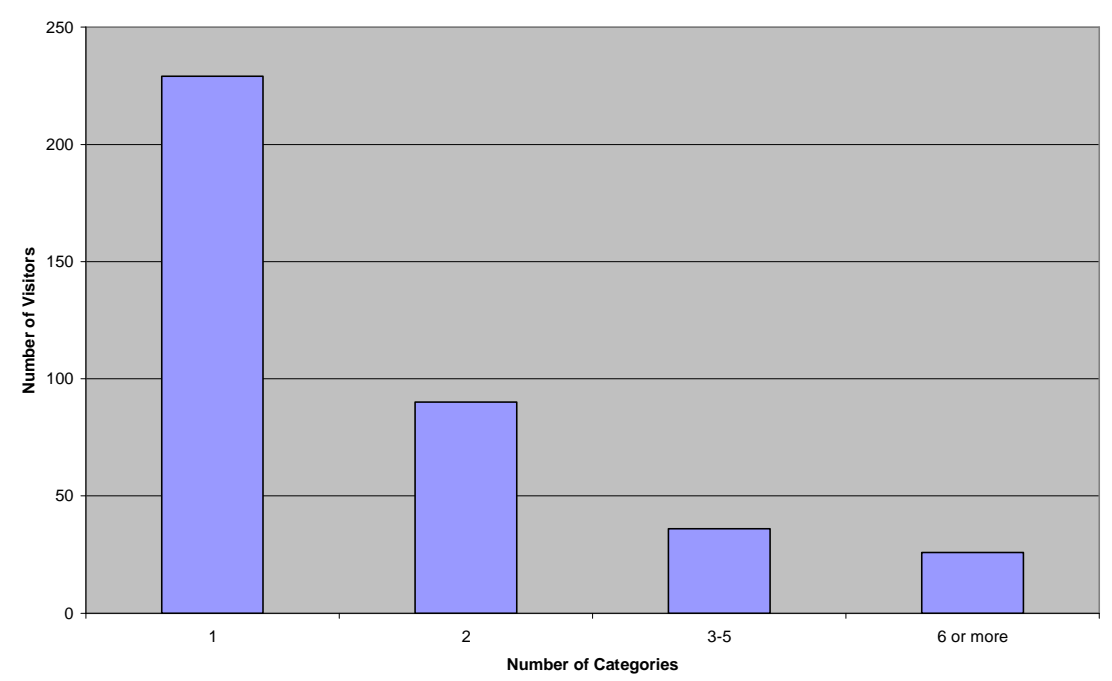

This graph shows how many categories each user accessed. Very few users viewed more than 2 categories. 


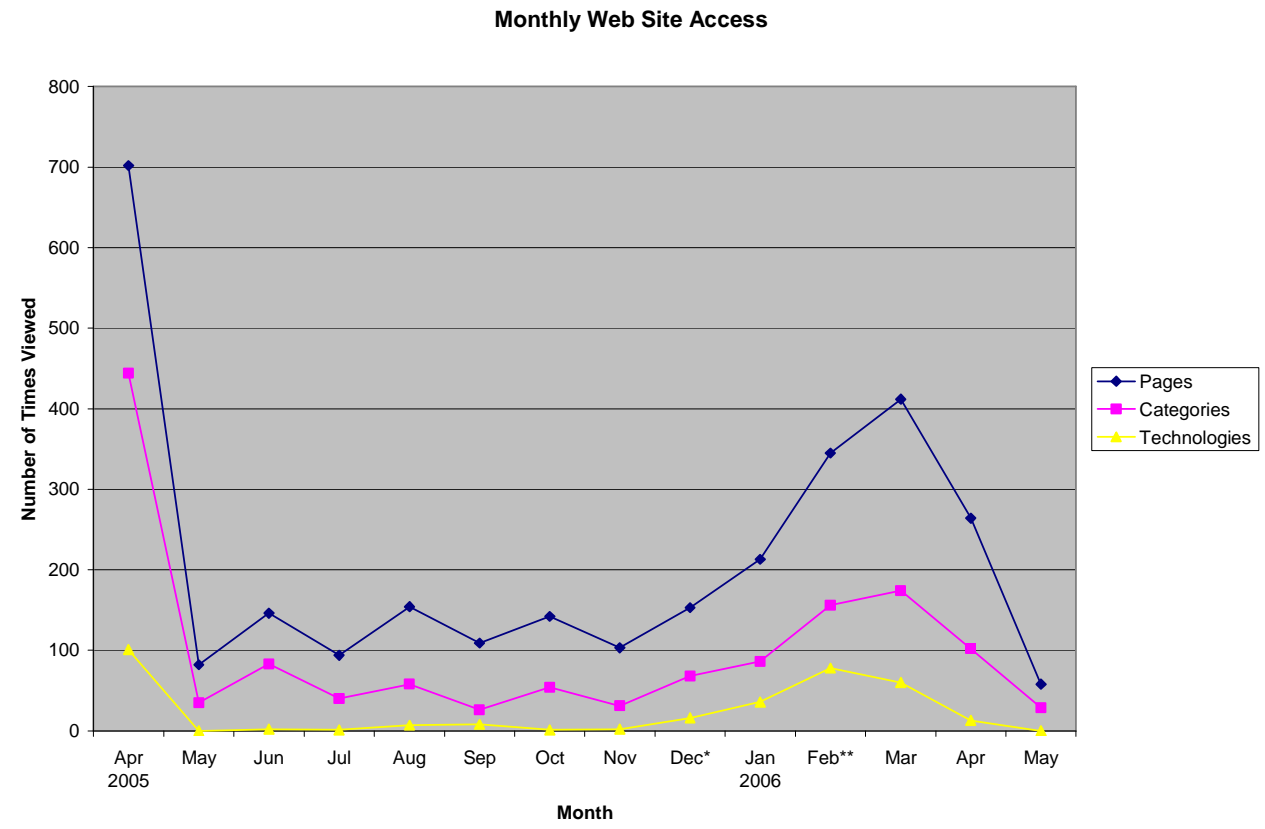

- * An additional 1595 pages, 65 categories, and 1525 technologies were viewed on Dec. 7, 2005 by users from Nicholls State University.

- $\quad * *$ An additional 243 pages, 81 categories, and 161 technologies were viewed on Feb. 24, 2006 by users from Nicholls State University.

- This anomalous data was removed from the graph for continuity.

This graph shows how many pages, categories, and technologies were viewed by users on a month-by-month basis. As described above, large numbers of hits from NSU were eliminated. It appears as though there was initially a lot of interest, but it quickly faded. Interest began to rise at the beginning of 2006. In May 2006, there were only 8 days of data available. 
Pages Viewed Per Month

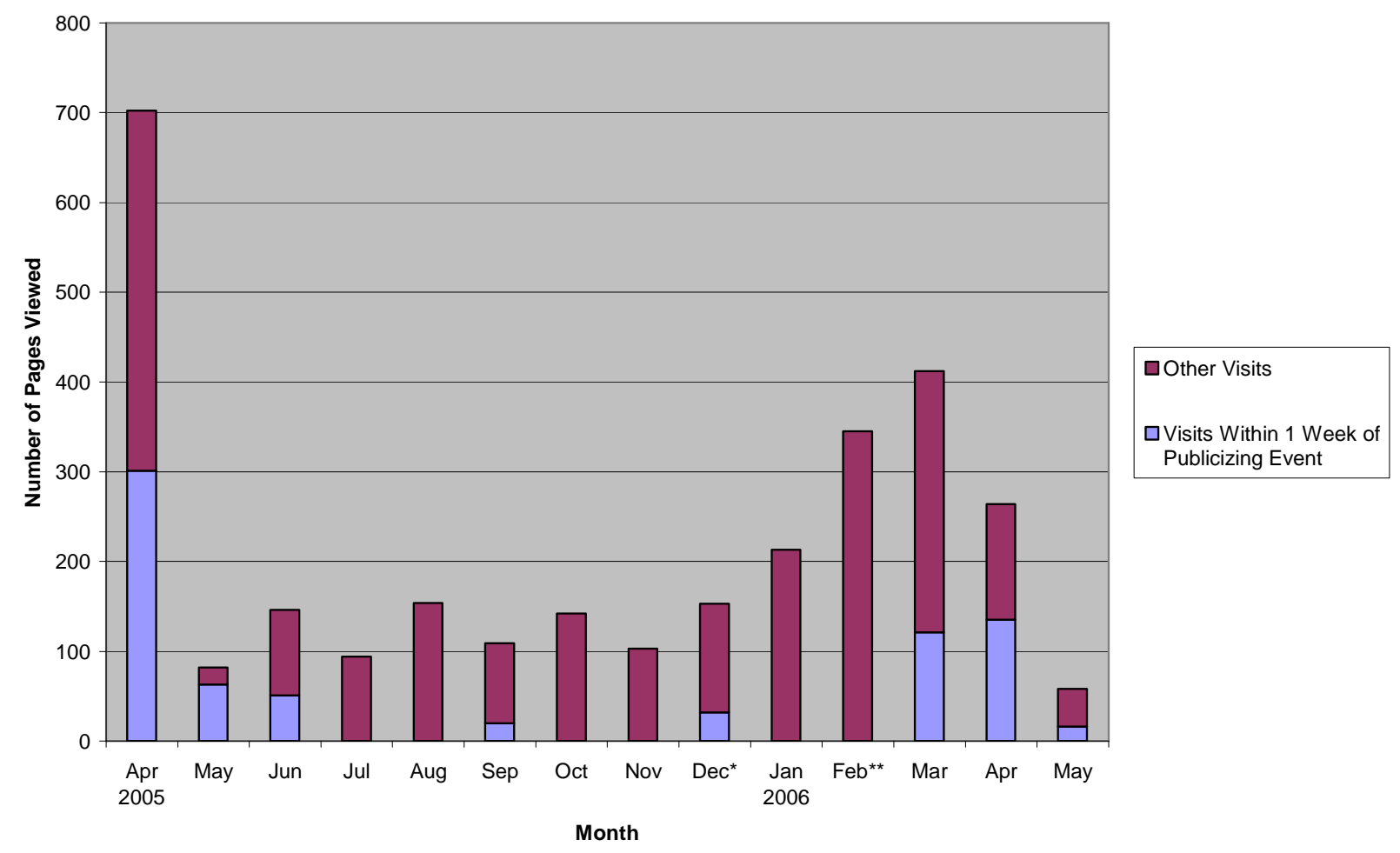

- * An additional 1595 pages were viewed on Dec. 7, 2005 by users from Nicholls State University.

- ** An additional 243 pages were viewed on Feb. 24, 2006 by users from Nicholls State University.

- This anomalous data was removed from the graph for continuity.

This graph is an attempt to show whether the hits we have are due primarily to publicizing events by showing which hits were within 1 week of a publicizing event. It appears as though most of the hits were not within 1 week of a publicizing event. The events used are listed below.

Publicizing Events

\begin{tabular}{|c|c|c|}
\hline $\begin{array}{r}5 / 3 / 2005 \\
5 / 12 / 2005\end{array}$ & $\begin{array}{l}\text { Houston } \\
\text { Norfolk, VA }\end{array}$ & $\begin{array}{l}\text { OTC } \\
\text { Crane Demo } \\
\text { Sponsor meeting: Hull Inspection/Environmentally }\end{array}$ \\
\hline $5 / 19 / 2005$ & Houston & Friendly Drilling systems \\
\hline $5 / 23 / 2005$ & Bethesda, MD & Catalog \\
\hline $6 / 14 / 2005$ & Houston & Noble- Potential projects meeting \\
\hline 9/20/2005 & Houston & Sponsor meeting: Catalog entries \\
\hline $12 / 16 / 2005$ & Houston & RPSEA meeting \\
\hline 3/15/2006 & Houston & Speaker: Canadian Environmental Solutions for the Energy Industry \\
\hline 3/16/2006 & Houston & Canadian Environmental Solutions for the Energy Industry \\
\hline 3/20/2006 & Houston & GPM: Discuss STTP \\
\hline $3 / 21 / 2006$ & Houston & Sponsor meeting: Corrosion Control \\
\hline $3 / 24 / 2006$ & College Station & Texas A\&M \\
\hline $3 / 26 / 2006$ & Thibodaux, LA & STTP Review and workshop \\
\hline
\end{tabular}


$4 / 21 / 2006$

$4 / 24 / 2006$

$4 / 25 / 2006$

$4 / 26 / 2006$
New Orleans, LA Thibodaux, LA Thibodaux, LA Houston
Speaker "Transition into the Hydrogen economy" STTP Review and workshop Nicholls State: Catalog details ExxonMobil

Effect of Publicizing Events on Number of Visitors (7 Day Moving Average)

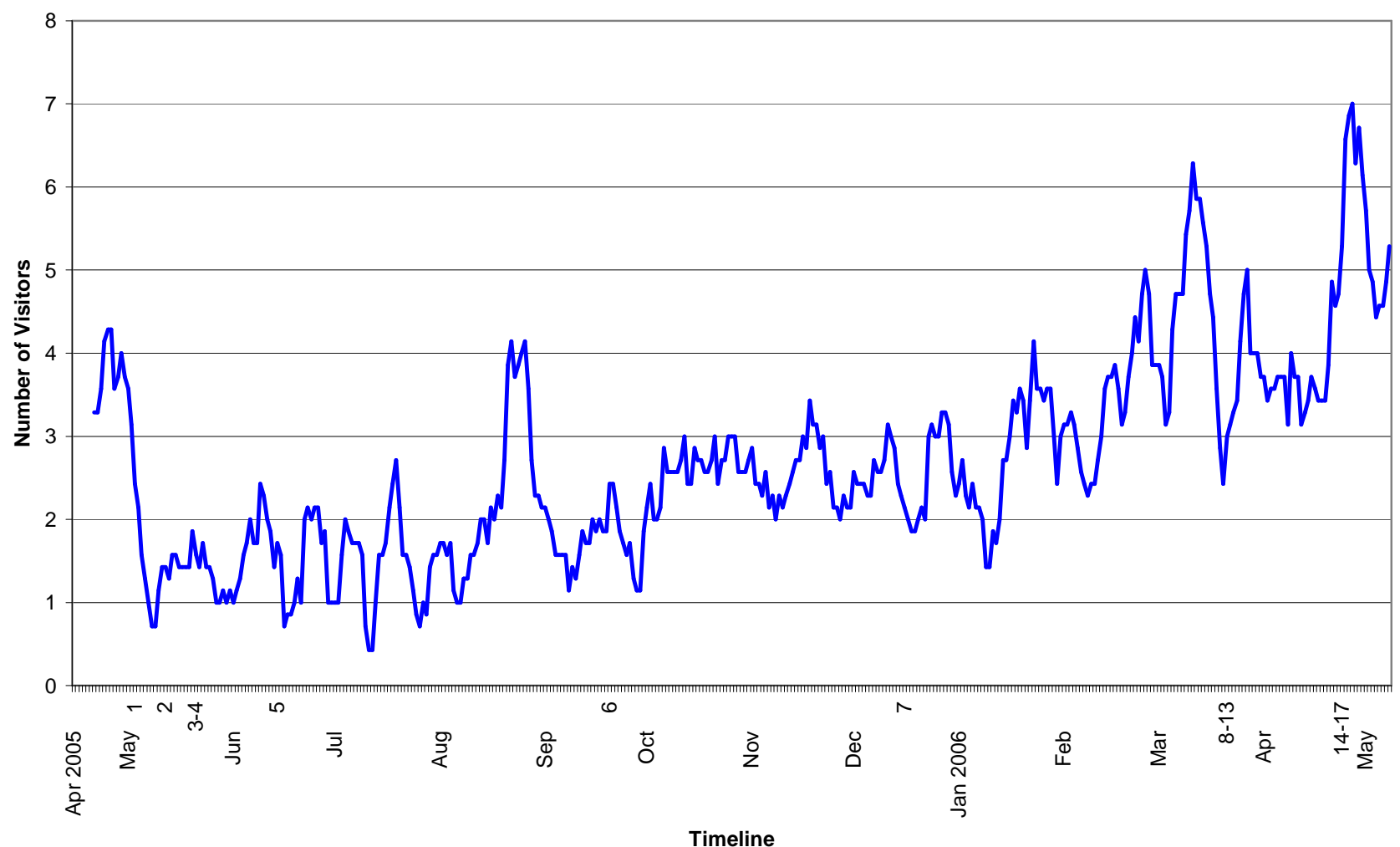

This graph shows the 7-day moving average of the number of unique IP addresses visiting per day. Publicizing events are listed on the $\mathrm{x}$-axis to see their impact. 
Effect of Publicizing Events on Pages Viewed (7 Day Moving Average)

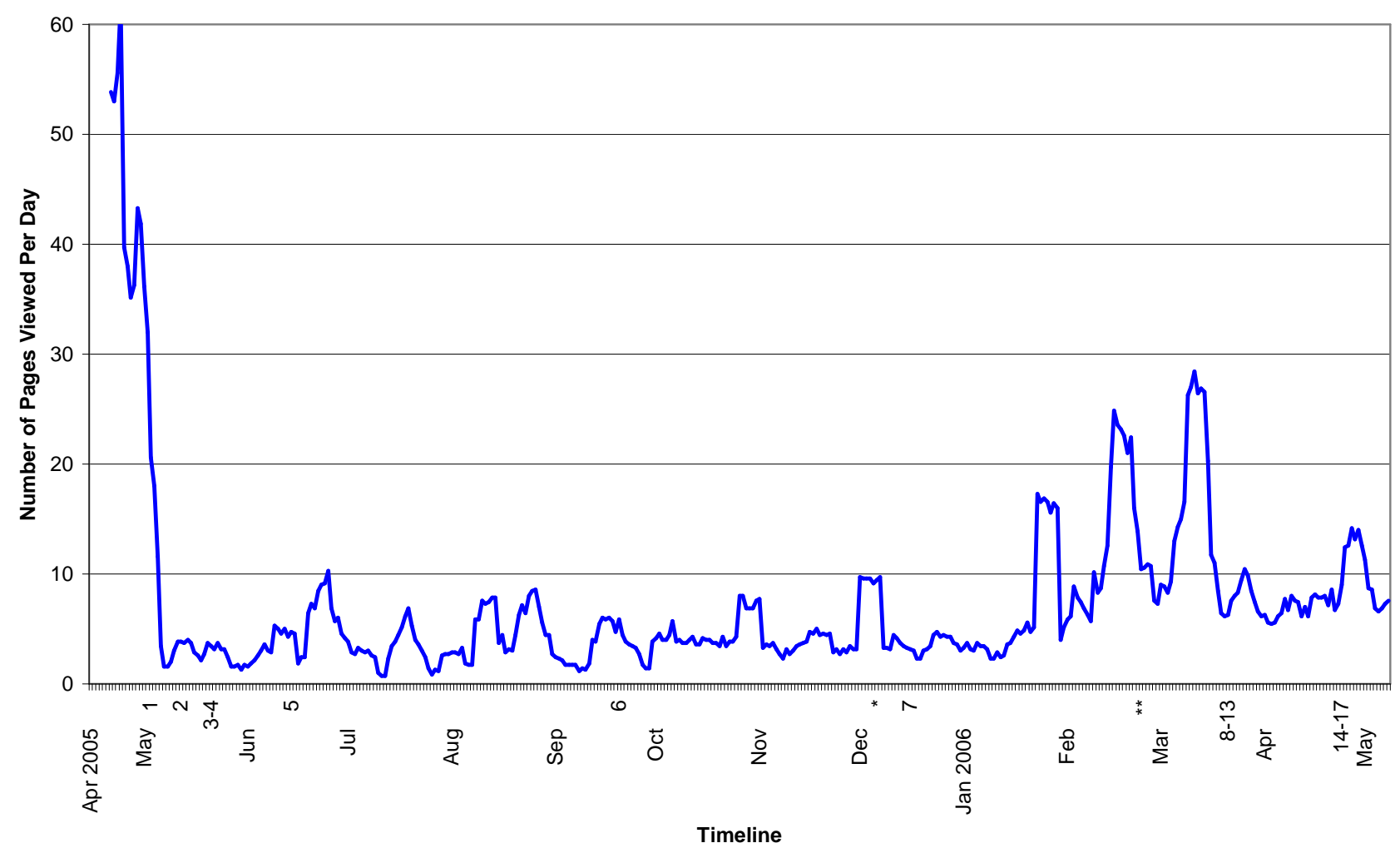

- * An additional 1595 pages were viewed on Dec. 7, 2005 by users from Nicholls State University.

- ** An additional 243 pages were viewed on Feb. 24, 2006 by users from Nicholls State University.

- This anomalous data was removed from the graph for continuity.

This graph shows the 7-day moving average of the number of pages viewed per day. Publicizing events are listed on the $\mathrm{x}$-axis to see their impact.

Publicizing Events

$\begin{aligned} 5 / 3 / 2005 & \text { Houston } \\ 5 / 12 / 2005 & \text { Norfolk, VA } \\ 5 / 19 / 2005 & \text { Houston } \\ 5 / 23 / 2005 & \text { Bethesda, MD } \\ 6 / 14 / 2005 & \text { Houston } \\ 9 / 20 / 2005 & \text { Houston } \\ 12 / 16 / 2005 & \text { Houston } \\ 3 / 15 / 2006 & \text { Houston } \\ 3 / 16 / 2006 & \text { Houston } \\ 3 / 20 / 2006 & \text { Houston } \\ 3 / 21 / 2006 & \text { Houston } \\ 3 / 24 / 2006 & \text { College Station } \\ 3 / 26 / 2006 & \text { Thibodaux, LA } \\ 4 / 21 / 2006 & \text { New Orleans, LA } \\ 4 / 24 / 2006 & \text { Thibodaux, LA } \\ 4 / 25 / 2006 & \text { Thibodaux, LA } \\ 4 / 26 / 2006 & \text { Houston }\end{aligned}$

OTC

Crane Demo

Sponsor meeting: Hull Inspection/Env Friendly Drilling systems Catalog

Noble- Potential projects meeting

Sponsor meeting: Catalog entries

RPSEA meeting

Speaker: Canadian Environmental Solutions for the Energy Industry

Canadian Environmental Solutions for the Energy Industry

GPM: Discuss STTP

Sponsor meeting: Corrosion Control

Texas A\&M

STTP Review and workshop

Speaker "Transition into the Hydrogen economy"

STTP Review and workshop

Nicholls State: Catalog details

ExxonMobil 


\section{Most Popular Technologies}

\begin{tabular}{|c|c|c|}
\hline Technology & $\begin{array}{l}\text { Categories Associated with } \\
\text { Technologies }\end{array}$ & $\begin{array}{l}\text { Viewed } \\
\text { by How } \\
\text { Many } \\
\text { Visitors } \\
\end{array}$ \\
\hline \multicolumn{3}{|c|}{ Viewed by 10 or More Visitors } \\
\hline Advanced Ceramics & Materials & 11 \\
\hline Fuel Cells & $\begin{array}{l}\text { Electrical, Hydrogen Technologies, } \\
\text { Chemical Process }\end{array}$ & 11 \\
\hline \multicolumn{3}{|c|}{ Viewed by $5-10$ Visitors } \\
\hline Design, Evaluation \& Ship Performance & $\begin{array}{l}\text { Hull Forms, Other Fluid Dynamics, } \\
\text { Programs }\end{array}$ & 9 \\
\hline Machinery Design Optimization & $\begin{array}{l}\text { Machinery Silencing, Mechanical, } \\
\text { Programs, Smart Ship Technology }\end{array}$ & 7 \\
\hline Metal Matrix Composites & $\begin{array}{l}\text { Materials, Fabrication Methods, } \\
\text { Materials and Alloys, Fabrication } \\
\text { Methods }\end{array}$ & 6 \\
\hline Underwater Hull Husbandry Robot & Inspection/Maintenance Techniques & 5 \\
\hline Subsea Acoustic Transmission & $\begin{array}{l}\text { Communications, Wireless } \\
\text { Communications }\end{array}$ & 5 \\
\hline Grapple Anchor Device for Underwater Towing of Watercraft & $\begin{array}{l}\text { Mechanical, Mooring and Lifting } \\
\text { Lines, Other }\end{array}$ & 5 \\
\hline Fiber Optic Loose Tube Buffer to Fan-Out Tube Adapter System & Fiber Optic Connector & 5 \\
\hline \multicolumn{3}{|c|}{ Viewed by fewer than 5 Visitors } \\
\hline Anti-Tilt Mooring System & Mooring and Lifting & 4 \\
\hline Fire-Resistant Barriers for Composite Materials & $\begin{array}{l}\text { Materials, High Temperature } \\
\text { Applications, Materials, Safety }\end{array}$ & 4 \\
\hline Fatigue and Crack Growth & $\begin{array}{l}\text { Fatigue and Crack Growth, } \\
\text { Inspection/Maintenance Techniques }\end{array}$ & 4 \\
\hline Discriminate Reduction Data Processor & $\begin{array}{l}\text { Data Transmission/Storage, Other, } \\
\text { Smart Ship Technology }\end{array}$ & 4 \\
\hline Anti-Sway Device for Hoists and Cranes & Mechanical, Systems, Safety & 4 \\
\hline Pressure Compensated Potable Water Chlorinator & Machinery, Safety & 4 \\
\hline Power Systems Modeling & Electrical, Programs & 4 \\
\hline Acoustic Jammer and Torpedo Decoy & Other, Security Systems & 4 \\
\hline Acoustic Decoy and Jammer & Other, Security Systems & 4 \\
\hline Non-Destructive Evaluation & $\begin{array}{l}\text { Sensors, Inspection/Maintenance } \\
\text { Techniques, Testing }\end{array}$ & 4 \\
\hline Submarine Communications System & $\begin{array}{l}\text { Wireless Communications, Data } \\
\text { Transmission/Storage }\end{array}$ & 3 \\
\hline Signal Processor for Narrow Band Sonar Signals & $\begin{array}{l}\text { Communications, Data } \\
\text { Transmission/Storage }\end{array}$ & 3 \\
\hline Advanced Crane Systems & Systems & 3 \\
\hline
\end{tabular}




\begin{tabular}{|l|l|r|} 
Landing Impact Absorbing Deployment System for Aircraft with & & 3 \\
Damaged Landing Gear & Safety & 3 \\
\hline Overboard Rescue System & Safety & 3 \\
\hline Smart Ship Technology & Machinery, Smart Ship Technology & \\
\hline & Mechanical, Mooring and Lifting & 3 \\
\hline Unmanned Watercraft Retrieval System & Lines, Smart Ship Technology & 3 \\
\hline Noise Control Composite & Machinery Silencing, Applications & 3 \\
\hline Fireproof Barrier System for Composite Structure & Applications, Applications, Safety & 3 \\
\hline Autonomous Sea Vehicles & Smart Ship Technology & 3 \\
\hline Material and Method for Fast Generation of Hydrogen Gas and & Hydrogen Technologies, Chemical & 3 \\
\hline Steam & Process & \\
\hline Ship Force Protection & Safety & 3 \\
\hline Fuel Cell Laboratory & & 3 \\
\hline Tow Basin Test Facility & Electrical, Hydrogen Technologies, & 3 \\
\hline Booster Rocket Range Safety & Chemical Process, Testing & \\
\hline & Testing & 3 \\
\hline Paints and Coatings-General & Safety & 3 \\
\hline Automated Skills Program & Corrosion Prevention, Mooring and & Lifting Lines \\
\hline
\end{tabular}




\section{Appendix C}




\section{Commercialization of Big Government Technology Created in Maryland, through SMEs in Louisiana: Design and Performance Metrics for the Shared Technology Transfer Program}

Thomas A. Bryant, ${ }^{1}$ K. Chris Cox, ${ }^{2}$ John M. Griffin, ${ }^{3}$ Ken H. Chadwick, ${ }^{4}$ Ronnie A. Fanguy, ${ }^{5}$ Rene' Charles Viosca, ${ }^{6}$ George W. Watt, ${ }^{7}$ R. Morris Coats, ${ }^{8}$ Rich Haut. ${ }^{9}$

Nicholls State University and the Houston Advanced Research Center

A paper proposal for the $19^{\text {th }}$ Annual UIC Research Symposium on Marketing and Entrepreneurship, San Francisco, August 1-3, 2005

"Two-page paper proposals should contain a cover page and headings for the following: (1) The Research Problem and Relevance, (2) Research Questions / Hypotheses, (3) Methodology, and (4) Expected Contributions to Practice and / or Theory."

\section{Abstract}

The Shared Technology Transfer Project (STTP), or Carderoc project, is an effort to find the best ways to commercialize the economic potential created in a large military-focused government R\&D lab. Part of the project deals with over 1,000 small and medium-sized enterprises as potential commercialization channels. These entrepreneurial firms and their owners have both existing products and markets, and much latent potential to make creative use of the Carderoc technology engine. Finding ways to bridge the cultural chasms between government-military lab and bayou entrepreneurs is a critical part of realizing the market potential of the taxpayer-supported capability of the Carderoc labs. Delphi and Bayesian techniques are being developed to attack the problem.

1 Co-Principal Investigator, Bollinger Family Endowed Chair in Entrepreneurship, College of Business, Nicholls State University.

2 Co-Investigator; Dept. Head and Associate Professor of Marketing, Dept. of Management and Marketing, College of Business, Nicholls State University.

3 Principal Investigator; Associate Professor of Petroleum Services, College of Arts \& Sciences, Nicholls State University.

4 Co-Investigator; Associate Professor of Management, College of Business, Nicholls State University.

5 Co-Investigator; Assistant Professor of Computer Information Systems, College of Business, Nicholls State University

6 Co-Investigator; Assistant Professor of Marketing, College of Business, Nicholls State University

7 Co-Investigator; Associate Professor of Manufacturing Technology, Dept. of Applied Sciences, College of Arts \& Science, Nicholls State University.

8 Co-Investigator; Argent Bank Endowed Professor of Economic, College of Business, Nicholls State University.

9 Director, Sustainable Technologies, Houston Advanced Research Center. 


\section{THE RESEARCH PROBLEMS AND RELEVANCE}

After prolonged negotiations, the Shared Technology Transfer Program (STTP) was funded in the federal US budget for FY 2004-2005. It provides nearly $\$ 1$ million to Nicholls State University for a project to transfer declassified technology from the Navy's Carderoc laboratories in Maryland to commercial firms in Louisiana and Texas. Much of the work is in the nature of a pilot project. While technology has been transferred from federal agencies to commercial entities in the United States for more than a century, there is much in the current project that is experimental.

The two principal delivery agents are Nicholls State University (NSU), a regional school serving the marine-intensive parishes of south central Louisiana, and the Houston Advanced Research Center (HARC). HARC is strongly connected to some very large professionally managed firms in south Texas, while NSU primarily serves entrepreneurial small and medium-sized enterprises in Louisiana. These firms cover a full spectrum of sizes, and levels of experience working with large public sector organizations.

It is the US government's wish to return the taxpayers' investment in Carderoc's technology as effectively and efficiently as possible. In order to do that, we must find ways to maximize commercialization - including reaching many firms that have never participated in this type of endeavor. Very large firms have cadres of intellectual property (IP) specialists, access to dealmakers, lawyers, and engineering teams. Many have long experience working with the US government, and with military organizations. As the size and age of firms decreases, these factors are less and less in evidence. Most small firms have none of these resources readily available. Yet, some of the nation's most entrepreneurial firms are in these categories. Indeed, the SME-dominated south Louisiana region has one of the highest patenting rates in the country, and many local fortunes have been made through the commercialization of marine-related technologies.

The situation represents a severe dichotomy in several dimensions. In terms of size, the Carderoc lab has 3,000 technical staff, working in nearly 200 sublaboratories, on advanced technologies. The Louisiana firms are dispersed, generally much smaller, and focused on commercial applications. Bridging differences in size, culture, location, and managerial focus poses substantial problems.

We have approached the south Louisiana market as one with 1,500 smaller firms in the marine sector. The challenge is how to match 165 sublaboratories and their technologies in Maryland with creative entrepreneurial talent in 1500 Louisiana firms. The Carderoc technology 
engine is poorly reflected in over 600 declassified patents. While 600 patents is a substantial portfolio of intellectual property, patents last 20 years, and many take several years to confirm. Thus any given patent could reflect state-of-the-art technology - for 1980! Even the newest patents will be at least 2 years out of date by the time the patents are issued. Furthermore, patents are only the public and historical portion of an R\&D organization. Much greater value lies in the unpatented know-how and research capabilities of the organization. From a user's perspective, the greatest value lies in the fuzziest assets - the ability to work with good scientists and wellequipped engineers to solve commercially valuable problems identified by the client's own sales and product development groups.

\section{RESEARCH QUESTIONS/HYPOTHESES}

As a result, we have developed a program model in which we try to combine the best of several different approaches.

One of the key questions facing this project team is "How do we select the technologies most ready for commercialization?"

Related to that is the demand-side question: "How do we identify the companies most ready to adopt new technologies?"

In some respects, those are complex questions when dealing with the range of technologies (over 600 patents and over 160 clusters / sub-labs) and companies (at least 1500). In other respects, those are problems that have been addressed before, and for which there are know methods of solution.

What makes this project special is the team's effort to optimize a many-tomany match-making system. We have asked a critical question: "What's the best way to match many technology-based opportunities with many different kinds of firms?"

We acknowledge from the beginning that the technologies vary across a wide range of "readiness" which we have converted into a nine-point Technology Readiness Index (TRI). We also acknowledge that the recipient firms vary across a wide scale of technological interests and capabilities, and across a full spectrum of entrepreneurial attitudes toward adopting outside technologies. As the middlemen in this latent market, our task is to find the best ways to maximize the rate of successful commercialization, to "birth" a new market in such a way that it realizes as much of the inherent opportunity as possible. 
We also understand our job to be to develop transferable models for this kind of market development. Our technology engine (the Carderoc Labs) and our recipient companies are typical of many such latent markets. "What are the best ways to bridge regional, corporate, and sector differences in culture? What are the best ways to use the power of a diverse entrepreneurial community to unlock the economic value of technological capabilities in large government (or corporate) R\&D organizations?"

\section{METHODOLOGY}

The project team has developed an initial three-level model of impact and a related set of measurement tools to track early performance. The project is experimental, consisting of a series of embedded pilot projects, so we expect to make changes as the learning curve moves.

One approach is to cast a broad net, and claim credit for anything that happens, a type of randomized incrementality model. A radically different management model is to analyze carefully both the origins (Carderoc) and the destinations (Louisiana firms), and try to execute a form of matching. The former approach seems very inefficient, and cedes control of the process. The latter involves a level of analysis and determination that are unlikely to be effective when so many of the destination firms are small and entrepreneurial. The entrepreneurs are of special interest partly because they hold the potential for creative new applications. As a result, even if we did detailed inventories of existing technological capabilities, that approach would not be able to pre-identify their potential interests.

At the base is an adoption-stratification model. It assumes that some entrepreneurs, some firms will be eager and curious, while others will be hesitant to investigate new technologies and relationships. Next, we defined firms according to the volume of their likely consumption of Navy technologies. Firms with likely multiple deals are being addressed with a portfolio approach, strong relationship links, and cluster affinities. Firms, usually smaller ones, with less defined interests are being addressed with a layered communication and opportunity identification strategy. More intense likely users are being served with more intensive resources, against which commercialization yields can be measured directly, firm by firm. Firms with less likely pay-offs are being grouped in ways that assess outcomes in a Bayesian framework.

\section{EXPECTED CONTRIBUTIONS to PRACTICE AND THEORY}


This research is not expected to finally solve problems that have been the subject of ongoing work for decades. We do, however, expect to address the questions in light of that previous work, and to add to it.

We are particularly interested in developing efficient ways to the capabilities of big R\&D labs accessible to large groups of entrepreneur-led firms. We are likely to differentiate methods of dealing with large, medium-sized, and small firms. We hope to uncover ways to stimulate latent entrepreneurial interest, and especially to stimulate entrepreneurs to develop new markets for those technological capabilities.

The work addresses questions of theory in the discovery and communication of technology-based entrepreneurial opportunity across substantial cultural differences. It also focuses on issues of optimization under multiple uncertainties. Finally, it addresses the role of universities as middlemen, as market-makers, in the development of markets for commercializable technologies.

\section{REFERENCES}

(Slovic and Lichtenstein 1971; Brown 1981; Koyle 1995; Rogers 1995; Piper and Naghshpour 1996; Smith 1996; Bryant and Reenstra-Bryant 1998; Astebrö and Gerchak 1999; Edmondson 1999; Mitra, Kumar et al. 1999; Bozeman 2000; Allan 2001; Tidd, Bessant et al. 2001; Norton and Moore 2002; Gartner, Shaver et al. 2004; Dorf and Byers 2005)

Allan, M. F. (2001). "A review of best practices in university technology licensing offices." The Journal of the Association of University Technology Managers XIII.

"Many methods and modes of operation in the technology licensing office of major universities are similar. Reputation of the institution and quality of the faculty are important factors in the effectiveness, by any measure, of the technology licensing office. Small but important distinctions have been observed from one organization to another. Each characteristic must be considered in the macro- and microenvironments in which the TLO functions. Together, these conclusions provide the basis for recomendations for new and existing TLOs to consider."

This is essentially a republication of a report the author did as a consultant for the Japanese External TRade Organization (JETRO) when it was considering setting up a US East Coast office.

TLOs spend hundreds of thousands of dolars on patenting, usually through outside counsel, and next to nothing marketing the resulting IP. Particularly for smaller schools, this is nonsensical, since they don't have the profiles to attract the aggressive acquisitors. Similarly, the case management approach requires such a broad range of expertise that little is left for marketing.

Cites AUTM Survey data: Commercialization of university research produced \$40Billion in economic activity and 270,000 jobs in 1999 . It also generated $\$ 5 B$ in tax 
revenues. More than 340 spin-off companies were formed that year, with $82 \%$ of them forming in the same home state as the university of origin.

Universities focus on producing those local impacts, but often create staff frustration with their hybrid values of social benefit and revenue generation. Benefits are highly skewed in most portfolios, so the allocation of effort is an important resource choice.

Solid recommendations for novice TLO creators -- although they are long on the creation of overhead (oops -- intellectual capital) and short on accountability and outcome frameworks.

Useful, but dated, URLs and other Notes.

Astebrö, T. and Y. Gerchak (1999). Profitable advice: the value of information provided by Canada's Inventor Assistance Program. United States Association for Small Business and Entrepreneurship, San Diego, CA, USASBE.

A somewhat statistical treatment, in which the value of the information provided to inventors appears to exceed the price they pay for it. Shows a correlation, although not high levels of compliance, between advice given and subsequent behaviour. Based on a survey of ca. $20 \%$ of 1977-93 submissions to IAP, and a $75 \%$ survey response rate, giving a sample of 1093 respondents from a base of 8797 submissions.

Works through the logical chain of advised-inventor decisions, using a form of Bayesian analysis. Lots of assumptions, and the level of aggregate analysis leaves TB quite uncomfortable with the use of broad aggregate models in what may well be a significantly fractured set of behaviours. Uses expected value of return analysis.

Bozeman, B. (2000). "Technology transfer and public policy: a review of research and theory." Research Policy 29: 627-655.

(The author abstract is descriptive, not abstractive.) This is a lit review, organized around the idea of a "Contingent Effectiveness Model." He focuses on domestic transfer from universities and government labs.

Brown, R. L. (1981). NASA's interest in entrepreneurs for materials processing in lowgravity (MPLG). Frontiers of Entrepreneurship Research. K. H. Vesper. Wellesly, MA, Babson Center for Enterpreneurial Studies: 353-371.

Bryant, T. A. and R. Reenstra-Bryant (1998). "Technology brokers in the North American software industry: getting the most out of mismatched dyads." International Journal of Technology Management 16(1/2/3): 281-290.

Previous work has examined the role of various technology transfer agents and devices including mavens, alliances, databases, and contracts. Most of that work focuses on either dyadic relationships or personnel transfers to drive the communication of intellectual property.

Triadic relationships are growing in importance, with "technology brokers" serving an important intermediary role. These participants have recently been recognized as a separate category of intellectual property specialists. Particularly in 


\section{Commercialization of Big Government Technology through SMEs}

relationships involving at least one small firm, potential partners may not have sufficient expertise to overcome communication, negotiation, or confidence barriers to arrange successful deals. Brokers can, and do, help in those situations.

Large firms have different cultures and expertise available to them, compared to small firms. In industries where the development of new products is not highly capital intensive, much valuable innovation takes place in smaller firms. Yet those innovators often have insufficient capital, production and marketing expertise, or distributional power to take full advantage of their developments. Larger firms have those capabilities but, with those functions highly professionalized, may have difficulties dealing with smaller firms due to cultural differences.

A series of case studies and interviews in the North American software industry is the basis for this paper. The various roles played by technology brokers are examined in order to determine the skills and market positions at which they are most valuable and effective. Among the brokers are corporate employees, lawyers, consultants, other small firms, public servants, and commercialization agents. Models are presented which suggest the best practices for larger and smaller organizations to make use of technology brokers.

Dorf, R. C. and T. H. Byers (2005). Technology Ventures: From Idea to Enterprise. New York, McGraw-Hill.

New textbook for MBA courses in tech ventures.

Edmondson, D. R. (1999). "Local universities as a resource for local SMEs." Industry and Higher Education 13(5): 322ff.

"This paper reports on the preliminary findings of an innovative project based in the counties of Devon and Cornwall in the far south-west of the UK. The project's objectives are to achieve technology transfer between local universities and small and medium-sized enterprises (SMEs) and to develop the local universities as a resource for the region. The aim of the associated research is to collect experiences from the project and evaluate them against a number of best practices for technology transfer. At this stage the main conclusions are: (1) SMEs require technology capable of rapid commercial exploitation; (2) clustering of technology transfer to SMEs is very difficult to achieve; (3) the intellectual property position must be made clear from the start; (4) it is difficult to interest SMEs in a project such as this; and (5) only a very small number of academics are interested in developing products from their research."

Gartner, W. B., K. G. Shaver, et al., Eds. (2004). Handbook of Entrepreneurial Dynamics: The Process of Business Creation. Thousand Oaks, CA; London, UK, SAGE Publications.

38 papers by many of the leading empirical scholars in the field, based on the PSED database.

Koyle, W. L. (1995). Technology transfer: the missing links from lab to launch, Licensing Executive Society of USA/Canada: 18. 


\section{Commercialization of Big Government Technology through SMEs}

In order to translate its 3rd place position in support for $R \& D$ into something better than its 21 st place in commercialization, Canada will have to fill in the gaps, to become a stronger nation of technology managers who can move great ideas out of the lab and into the commercial marketplace.

Mitra, J., V. Kumar, et al. (1999). "The quiet Australian harvest: The science, technology, enterprise and economic development mix." Industry and Higher Education 13(5): 293ff.

"Abstract: Australia's outstanding economic success in recent years has been aided by significant developments in science and technology research and by the ways in which research has been exploited for commercial development. Australia's success in this respect, and its rapid and sometimes innovative development of such vehicles for R\&D exploitation as science and technology parks, makes it a suitable case for study. This paper arises from the findings of a study mission from the UK, which set out to identify and analyse the various ways in which Australia is addressing the challenge of science and technology exploitation. The authors focus on current science, technology and innovation policies at state and national levels, and assess the various ways in which science and technology parks have been used as vehicles for innovation, business development and economic regeneration. The paper is divided into three main parts: Part 1 discusses policy issues at state and Commonwealth levels; Part 2 is concerned with technology, innovation and economic regeneration and describes various science and technology park developments; and Part 3 assesses the ways in which university-industry links are manifested in science and technology parks. A concluding section summarizes the key aspects of Australia's strategy for economic development through science and technology, in terms of both policy and implementation."

Norton, W. I., Jr. and W. T. Moore (2002). "Entrepreneurial risk: Have we been asking the wrong question?" Small Business Economics 18(4): 281-287.

The literature is reviewed with a view toward integrating the risk assessment perspective. A decision framework based on the Bayesian probability model is introduced which formally allows differential assessments of possible outcomes due to differences in prior information. A numerical example is offered to show its impact on entrepreneurial decision making.

Entrepreneurs are often thought to engage in "risky" behaviors. Thus, they may be seen as more willing than average to take risks. We offer a dissenting view. Central to entrepreneurship is the alertness perspective which suggests that entrepreneurs may assess opportunities and threats differently than non-entrepreneurs. That differential assessment may be understood in terms of Bayesian probability. The Bayesian model argues that differing assessments of prospective outcomes may be attributable to differences in prior information. This perspective on risk assessment has implications for entrepreneurial decision making, whether to launch a new venture or adopt a growth strategy. The literature is reviewed, a synthesis is offered, a numerical example is developed, and a research agenda is proposed. 


\section{Commercialization of Big Government Technology through SMEs}

Piper, W. S. and S. Naghshpour (1996). "Government technology transfer: the effective use of both push and pull marketing strategies." International Journal of Technology Management 12(1): 85-94.

Rogers, E. M. (1995). Diffusion of Innovations. New York, The Free Press.

The innovation / adoption cycle started here.

Slovic, P. and S. Lichtenstein (1971). "Comparison of Bayesian and regression approaches to the study of information processing in judgment." Organizational Behavior and Human Performance 6: 649-744.

Smith, H. L. (1996). "National laboratories and regional development: case studies from the UK, France and Belgium." Entrepreneurship and Regional Development 8(1 (January-March)): 1-18.

Tidd, J., J. Bessant, et al. (2001). Managing Innovation: Integrating Technological, Market, and Organizational Change. Chicester, West Sussex (UK), John Wiley \& Sons, Ltd.

Comprehensive summary of the field of knowledge. 


\section{Appendix D}




\section{N S I D E \\ May 2, $2007 \bullet$ Vol. 18, No. 8

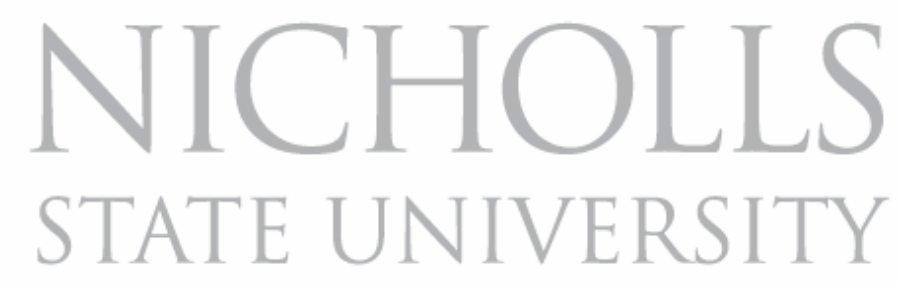

\section{Griffin travels to}

\section{Panama with delegation}

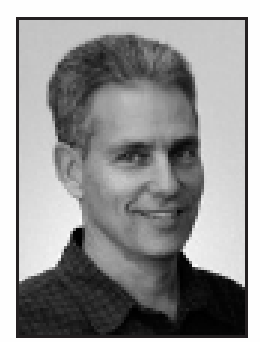

Griffin

Dr. John Griffin, associate professor of the petroleum services program, participated in the Louisiana Trade Mission to Panama in Central America to present information on shared U.S. Navy technologies April 15 to 19 . The delegation was coordinated by the Louisiana District Export Council in conjunction with the Louisiana Office of Economic Development, the U.S. Commercial Service, the Port of New Orleans and the city of New Orleans.

The group traveled to Panama to promote Louisiana as a partner in trade and transportation, international investments and tourism. They met with members of the American Chamber of Commerce and Industry of Panama, the Panama Canal Authority, U.S. ambassador William A. Eaton and other prominent Panamanian officials and business and professional leaders.

The Panama Canal is expected to expand its capacity and spend more than $\$ 5$ billion, which could mean increased business opportunities for Louisiana industries.

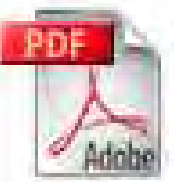




\section{Louisiana Trade Mission to Panama}

April 15-19, 2007

\section{Mission Report}

Prepared by:

Marisol Canedo

Coordinator, Louisiana District Export Council

Consultant, Louisiana Economic Development

\#2 Canal Street, Suite 2710

New Orleans, Louisiana 70130 


\section{Louisiana Trade Mission to Panama April 15-19, 2007}

\section{Mission Report}

The Louisiana District Export Council, Louisiana Economic Development, U.S. Commercial Service in New Orleans, in cooperation with the World Trade Center and the Port of New Orleans, organized a 16-member trade mission to Panama, April 15-19, 2007. (See attachment “A”- mission agenda and list of participants)

Prior to the mission's departure and to give Louisiana companies a better understanding of the opportunities available in Panama, the Senior Commercial Specialist at the U.S. Embassy in Panama delivered a presentation during the "Doing Business with Panama" breakfast briefing on March $13^{\text {th }}$ at the World Trade Center in New Orleans. Topics of discussion included the Canal expansion and procurement process, exporting to Latin America via Panama's Colon Free Trade Zone, major opportunities in the energy and construction industries and promoting Louisiana tourism and education in Panama. Eight individual appointments were prearranged with Louisiana companies and government agencies interested in participating on the Panama mission, followed by a Hurricane Katrina tour related to the devastated zones in Orleans and St. Bernard parishes. (See attachment "B" - March 13 presentation, list of attendees and agenda).

The co-leaders of the mission were: Geralyn Contini, Chair, Louisiana District Export Council and CEO of Schaffer \& Associates International, L.L.C., Richard House, Executive Counsel for Louisiana Economic Development; Lisa Ponce de Leon, Chief of Staff for Economic Development /International Business, Office of Planning \& Planning Development for the City of New Orleans and Ted Knight, Executive Assistant for Operations for the Port of New Orleans.

The primary areas of interest during the 3-day visit to Panama were trade and transportation, promoting Louisiana as a destination for international investments, tourism and other reciprocal interests with Panama. For example, in December 2006, the citizens of Panama approved a project to expand the capacity of the Panama Canal that will include construction of a third set of Canal locks to allow transiting of Post Panamax vessels. With a project cost estimated at $\$ 5.3$ billion, 7-8 years to complete and a US\$200 million in annual procurement opportunities, new prospects are opening for U.S. firms in dredging, engineering \& architectural equipment and services, construction and maritime equipment, materials \& supplies, and other related industries.

With Panama's growth and as a key trading partner for Louisiana's business and service industries, this trade mission represented an important opportunity to build commercial cooperation, to promote mutual economic growth and to explore Panamanian investment opportunities in Louisiana as a destination for international investments in the aftermath of Hurricanes Katrina and Rita. In addition to the high-level 
briefings and 28 one-on-one business meetings pre-arranged for American Construction Management Services, Industrial Utility Services Co., Inc., Schaffer and Associates International, L.L.C., Stuller,

Louisiana Economic Development and City of New Orleans, highlights of the mission's agenda included:

- The opening mission event was a breakfast briefing hosted by Pan American Life. As the leading provider of insurance for Latin America and the U.S. since 1911, Pan American provided an overview of products and services available for U.S. companies interested in operating in Panama.

- A special luncheon briefing on "Doing Business with Louisiana" was hosted by the American Chamber of Commerce for its members to meet and network with the Louisiana delegation and to learn about the "Gulf Opportunity Zone" (GOZone) incentives available for Panamanian investors to consider Louisiana as a destination for international investments.

- An informative briefing presented by the Panama Canal Authority on the canal's master plan for expansion and the selection and contracting process for projects on the canal. Following the presentation, members of the delegation received a guided tour of the Panama Canal Museum and a reception at the Miraflores Visitors Center in honor of the delegation while viewing ships transiting the lock chambers. (Note: master plan available upon request, selection and contracting process refer to: http://www.pancanal.com/eng/anuncios/promotion/presentations/panama-canalcontracting-system.pdf and see attachment for " $C$ " - list of reception invitees)

- U.S. Ambassador William Eaton hosted a reception at LaCresta, the Ambassador's residence, for members of the delegation to meet prominent Panamanian officials and business and professional leaders. The reception was sponsored by Louisiana Economic Development. The buffet showcased typical Panamanian dishes and Louisiana favorite recipes exchanged during the 2005 WTC mission by WTC's Plimsoll Club Chef. During the reception, a presentation of the U.S. Department of Commerce's "Certificate of Appreciation for Achievement in Trade" was awarded to Revista Mosaico, the weekly magazine of "La Prensa", for its dedication and valuable efforts in promoting Louisiana as a travel destination for Panamanians. (See attachment "D" - list of invitees and nomination for Revista Mosaico)

- The closing event was a visit to the Colon Free Zone (CFZ) via the Panama Canal Railroad. A detailed briefing was presented by the Marketing Director at the CFZ Administration on the world's second largest Free Zone entity located at the Atlantic gateway to the Panama Canal dedicated to re-exporting an enormous variety of merchandise to Latin America and the Caribbean. Following the presentation, members of the delegation visited Motta Internacional (the oldest and largest business established in the CFZ which is part of Grupo Motta with interests in the banking, real estate, automotive, insurance, and other sectors) and Casa Osaka for viewing of retail showcases in the CFZ. The delegation then visited Manzanillo International Terminal (MIT) where a briefing, tour (largest container port in Latin America) and luncheon was hosted by MIT. Concluding the visit, the delegation was briefed by a senior representative of J. Cain \& Co., a full service distribution center for Latin America and specialists in logistics services for multinational companies in the Colon Free Zone, followed by a tour of the facility.

Current information on Panama's economy, demographics, political structure, commercial and tourism information can be accessed via the following: 
- U.S. Department of State Background Notes on Panama: http://www.state.gov/r/pa/ei/bgn/2030.htm

- U.S. Embassy Country Commercial Guide on Panama: http://www.buyusainfo.net/docs/x 3421748.pdf

- General tourism on Panama visit: http://www.panamainfo.com

- The Panamanian Presidency, with links to all other government ministries and agencies: www.presidencia.gob.pa

Media and other related information:

- Ellas, supplement of LaPrensa, April 27 "Agasajan a Mision Comercial de Louisiana"

- El Panama America, April 24 "Coctel en la Embajada"

- $\quad$ La Prensa, April 22

"Mision Commercial de Louisiana"

- April 17 release

"Revista Semanal Promovio Opportunidades Despues del Huracan Katrina, Viajes y Comercio entre Louisiana y Panama"

- $\quad$ April 16 release

"U.S. Ambassador to Panama William Eaton Honors Revista Mosaico for Contributions to Trade"

- April 16 release

"Mision Commercial de Luisiana en Panama"

- $\quad$ El Panama America, April 17

"Empresas norteamericanas interesadas en la ampliacion"

- $\quad$ La Prensa, April 17

"Apertura para inversiones en Nueva Orleans"

- $\quad$ The Times -Picayune, April 13

- April 10 release

"Trade Mission to Panama"

"Louisiana Trade Mission Departs for Panama" listed the company names of the mission participants

- The Times-Picayune, March 6 "Panama trip planned"

- $\quad$ CityBusiness ads, March 5

"Doing Business in Panama" and "Louisiana Trade Mission to Panama

- Louisiana International Trade Bulletin, March

"March Business Briefing and April Trade Mission to Panama" (to view the bulletin, refer to the following link: http://www.wtcno.org/bulletin/2007/pdf/03-07.pdf)

- $\quad$ CityBusiness, February 28

“\$5.3 Billion Panama project options explored at WTC talk”

- February 27 release

"Louisiana Trade Mission to Panama \& Business Briefing on Panama in New Orleans"

- February 23 release

"Louisiana Trade Mission to Panama \& Business Briefing on Panama in New Orleans"

- Louisiana International Trade Bulletin, February

"March Business Briefing and April Trade Mission to Panama" (to view the bulletin, refer to the following link: http://www.wtcno.org/bulletin/2007/pdf/02-07.pdf)

- Commercial Service Staff contact information and U.S. Embassy in Panama 


\section{Appendix E}




\section{Navy initiates \\ technology transfer}

While there have been isolated incidents of private industry adopting technology developed by the military, there is a new, organized effort to make this technology readily available to the offshore industry. The Houston Advanced Research Center has entered into a cooperative research and development agreement with the Naval Sea Systems Command, Carderock laboratory (Navsea-Carderock) to take existing Navy-developed technology and apply it to the needs of the offshore industry.

The agreement provides a business and intellectual proverty framework that allows technology transfer between the Navy and industry to proceed quickly and efficiently, according to Richard Haut, director of HARC's engineering group

To effectively transfer the technology, the Blue Water Technology Program, an industryIed consortium, is being formed. While the vast maiority of the technology developed by Naval research is not classified, it can be daunting for private industry to identify the specific technologies that would best fit its needs. Blue Water will facilitate this process by culling through all available technologies and advising members on what solutions best fit the problem at hand. In some cases, industry members may have a problem and no idea how to solve it. in other cases, a company may initially consider one solution because it is unaware of other solutions that might be better fits.

Mike Wade, who represented Navsea-Carderock at the initial Blue Water meeting, said the Navy will make the technology available. HARC will then review it to define the technologies and intellectual properties that match offshore industry needs. Companies that choose to join HARC's efforts will work with Navsea-Carderock to design a technology transfer plan and map industry needs with Navsea-Carderock technologies and capabilities.

When a solution is identified, the Blue Water member will enter into a technology transfer agreement for the individual technologies. Prototyping and demonstrations will be conducted using the combined staffs and facilities of HARC, Navsea-Carderock, sponsor companies, and selected universities, If the decision is made to go forward, additional agreements will define the relationships between the parties and govern intellectual property rights. The goal is to speed technology migration from the laboratory to the offshore and maritime industry.

By transferring technology developed in Navy laboratories to support the US maritime and offshore industries. Navsea-Carderock works within its congressional charter and helps maintain dominance of $\mathrm{CS}$ ofisshore indus. try by advancing new technologies required by

\section{the ultra deep environment.}

This program should reduce the risk and cost of developing deepwater solutions for the industry because domestic companies can take full advantage of mature technologies previously developed by the U.S. Navy.

This should, in turn, shorten the time needed to develop ultra-deeproil and gas reserves, which would benefit the domestic petroleum industry and the federal and state governments.

Navsea-Carierock is an ideal source for such solutions. It is responsible for Navy surface and undersea vehicle research and development, testing and evaluation, in-service engineering logistics, and fleet support. Navsea-Carderock addresses Navy hull, mechanical and electrical systems, and propulsors, and is chartered by congress to support the domestic maritime industry. The Carderock Division evolved from the merger of the David Taylor Research Center in Carderock and Annapolis, and the Naval Ship Systems Engineering Station in Philadelphia. Navsea-Carderock employs over 3,000 people. of which more than 2,000 are research and engineering personnel. Areas of exper tise identified as having immediate potential for technology transfer to the of fshore industry include:

- High pressure seals/valves for use in harsh environments (temperature, pressure, corrosiveness)

- Materials science for development of advanced structural systems

- Acoustic signature removal - applications in 3D seismic data acquisition and process. ing

- Hydro-mechanical testing and modeling for ocean platorms, risers, and other systems exposed to strong surtace and sub-surface ocean currents

- Design/development of advanced power sources: turbines, generators, motors, and fuel cells

- Wireless communications/sensors - moni toring subsea facilities and remote operations. HARC is coordinating this effort with industry. HARC, a non-profit organization located sutside Houston, is a collaborative institution where industry, university, and government participants join to develop and commercialize technology that is important for the region and the country. HARC bas managed other government and industry collaborative efforts. such as the magnet design for the Superconducting Supercollider seismic imaging for oil and gas exploration, and fuel cell applications.

The goal will be to develop a panel of industry experts to shape the direction of this elfort, Haut said. Baserl on the key areas of technology identified by this board, HARC will mine the technologies available from the Navy and identify potential solutions. These will then be brought forward and commercialized by HARC and the sponsor members.

HARC is seeking industry support of the Blue Water Technology Program. Companies participate at two levels. First, they pay a sponsorship iee to join. This fee covers the cost of HARC review. ing and mapping the vast collection of data and advising members on how these technologies can be adapted to meet their needs. The second level of sponsorship kicks in when a solution is identified. The company, or companies, interested in developing and conmercializing the technology will pay the second level of sponsorship. This includes development and testing of the new technology and, in some cases, supporting funds from the government.

For more information on this program. contact Richard Haut at HARC at rhaut Qharcedu.

\section{Weatherford installs \\ TorkWinder for BP}

Weatherford has received an order from $\mathrm{BP}$ to install the North Sea's first "All in One" TorkWinder System on the ULA platform, in the Norwegian sector of the North Sea. The system reduces rig time and allows greater control over rig components, using a fully remote operated machine for make up of all casing, tubing, and drillpipe, including special tools and assemblies. Previous manually operated functions like cleaning, stabbing, "doping," and making up of stabilizers and drill bits are incor. porated in the system, in line with the new requirements from the Norwegian Petroleum Department for a fully remotely operated system.

\section{ABB supplies monitoring} systems in North Sea

Danish Oil and Natural Gas has tapped ABB to install a number of automatic monitoring tems for the enlargement of the Sini field in the North Sea. DONG is responsible for the supply. distribution, and storage of natural gas and oil within Denmark.

The contract indudes an order from Semed Maritime for a safety and automation system fot DONG's two new ummanned platforms for oil and gas production at the Nini and Cecilie fields, as well as a direct order from DONG for the existing Siri production field.

$\mathrm{ABB}$ will supply three basic systems: one system for normal process control and logging of data; an emergency shut down system primarily protecting the process equipment; and a fire and gas system.

An Operate IT operator station will control and monitor the Nini and Cecilie platforms. ABB: Industrial fT technology allows for real-time monitoring of all information. The ABB Control IT I/O modules chosen by DONG can be placed directly in hazardous areas, reducing cabling and heavy enclosures and saving on instaliation costs in the North Sea enviromment. 0 
Appendix F 


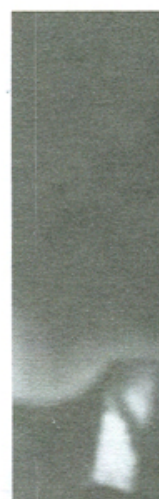

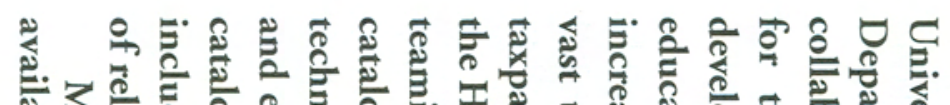

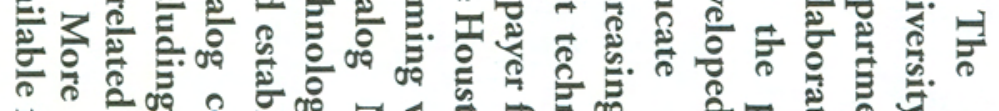

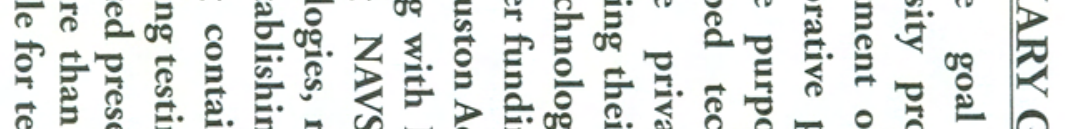

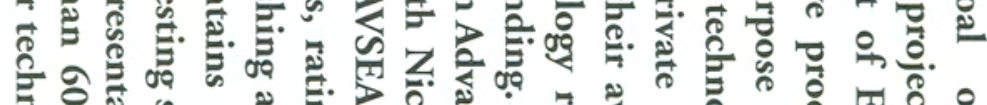

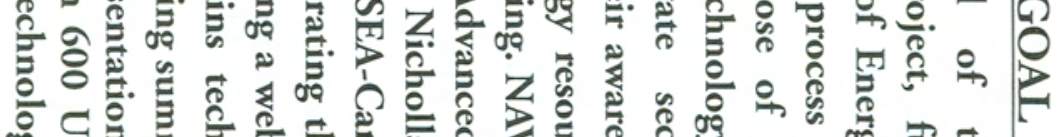

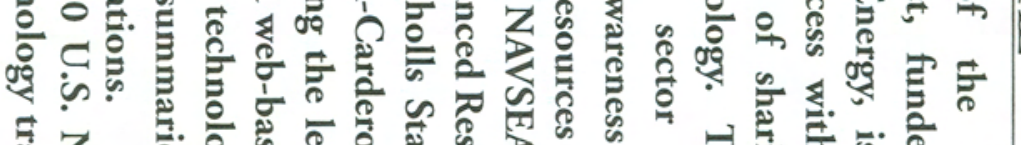

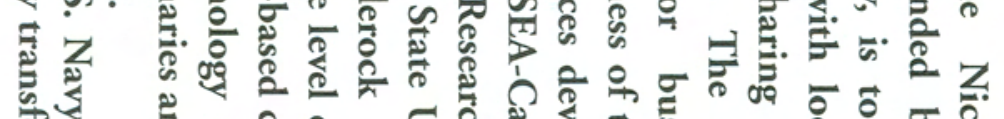
क्ष

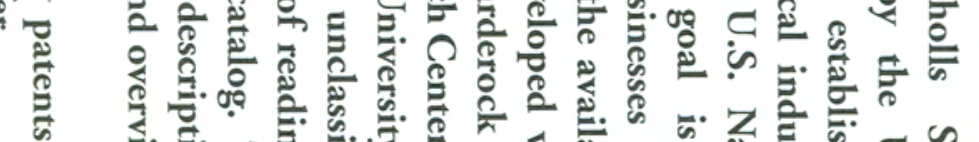

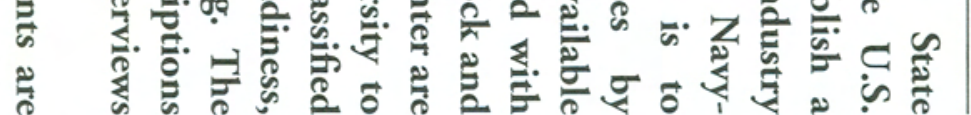

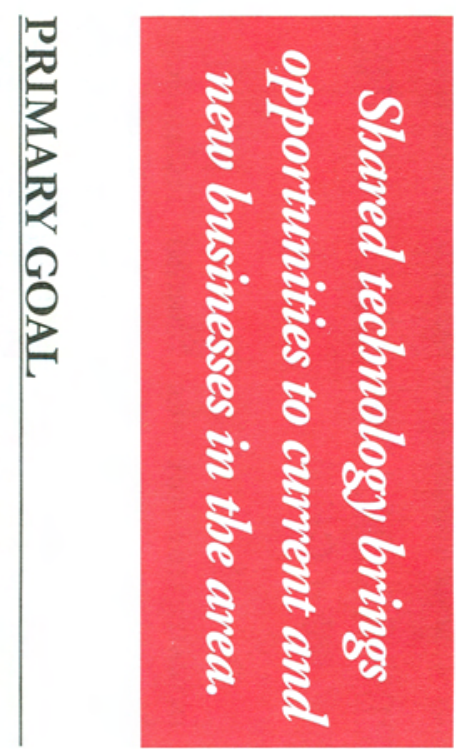

$\sum_{3} Z$

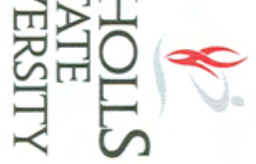

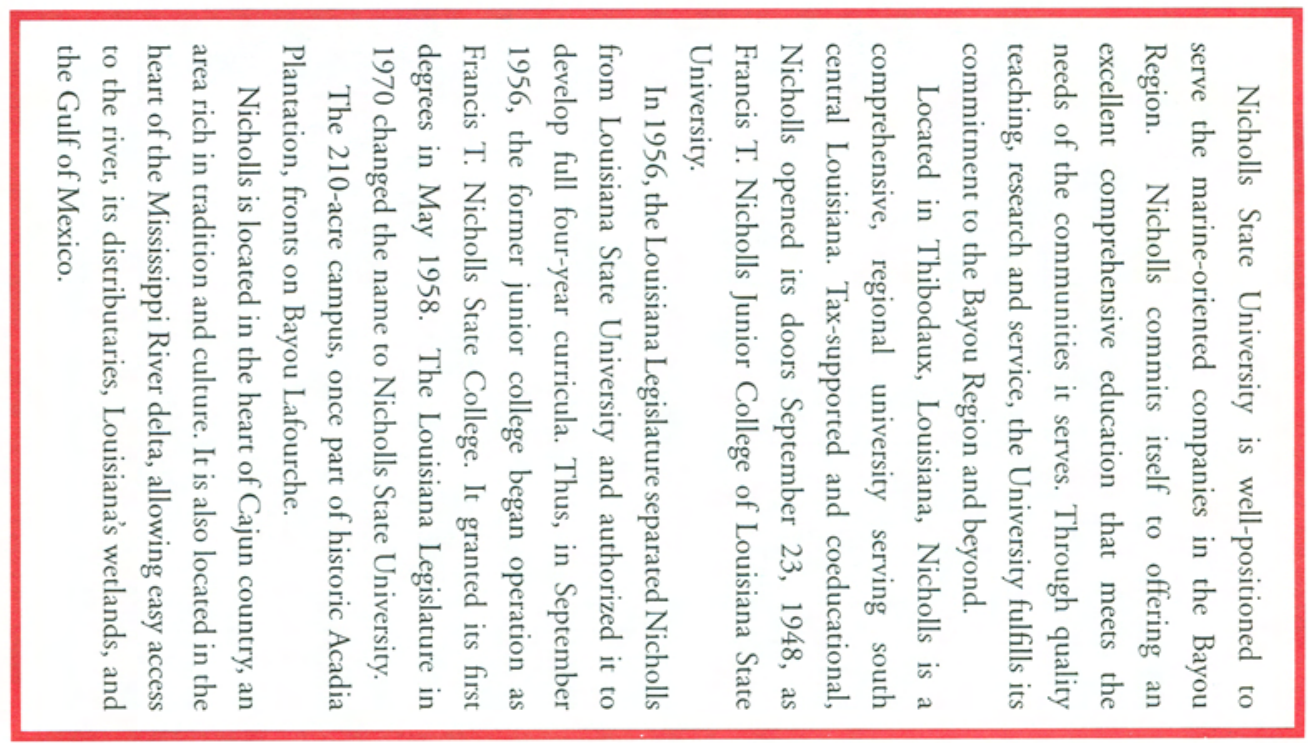

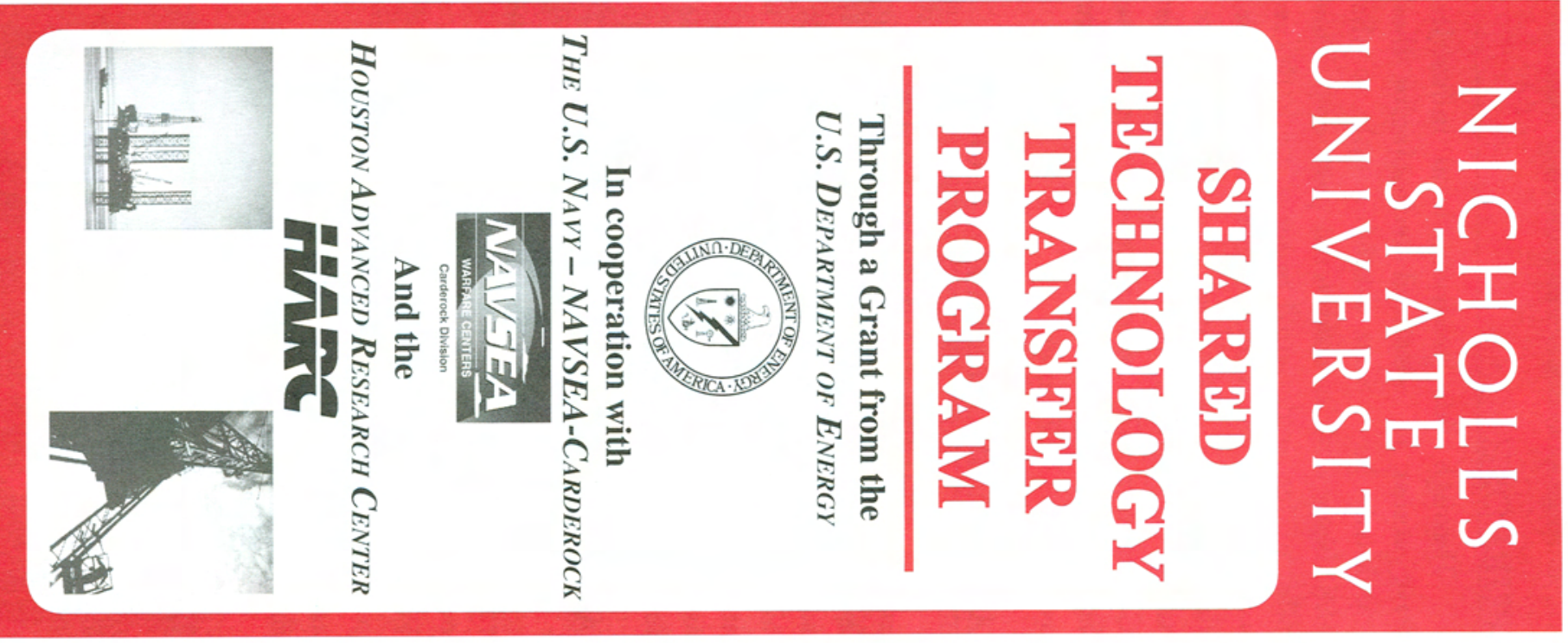




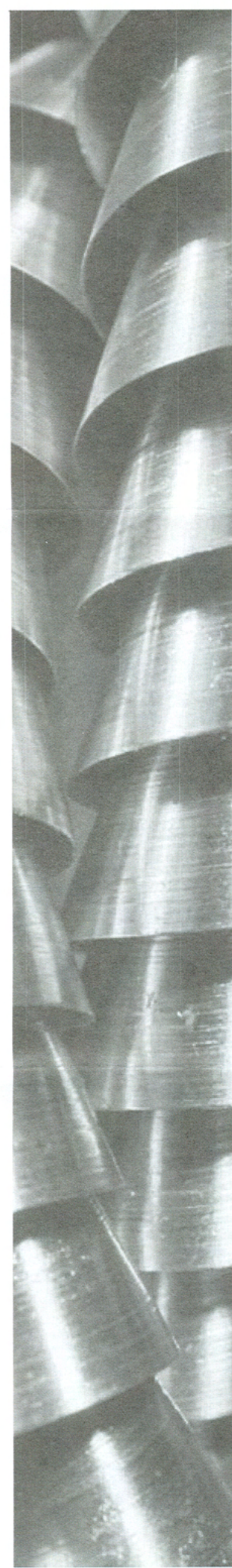

Pen⿳亠口冋⿴囗十

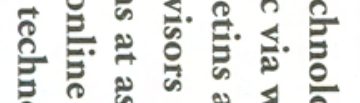

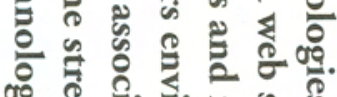

I

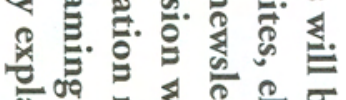

(n)

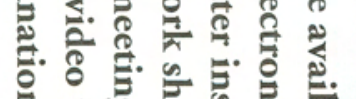

ำ

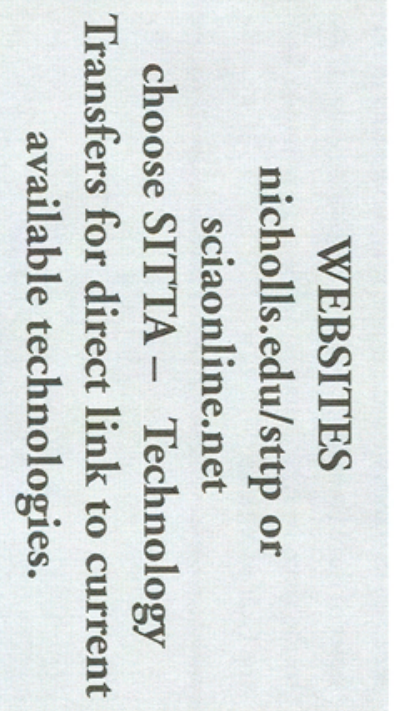

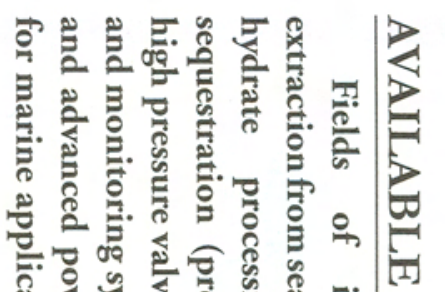

.

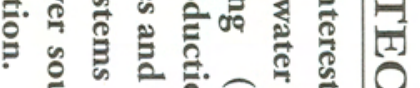

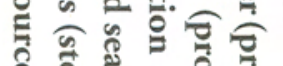

है है은

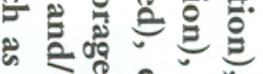

궁

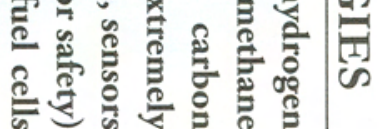

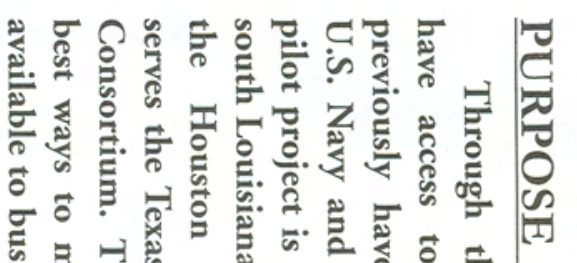

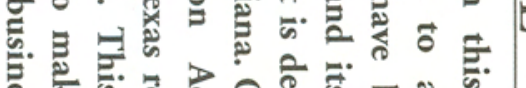

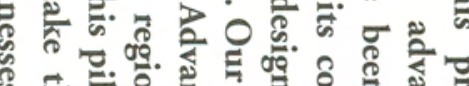

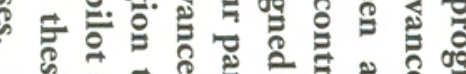

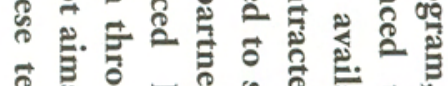

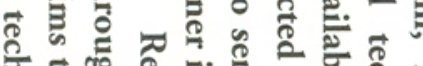

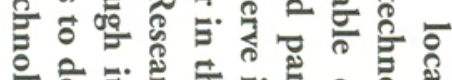

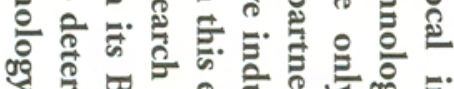

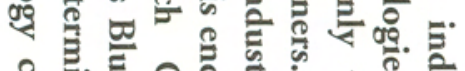

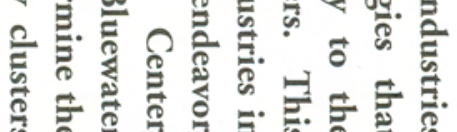

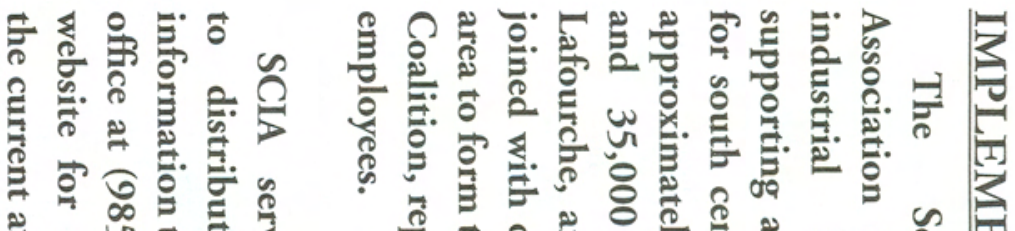

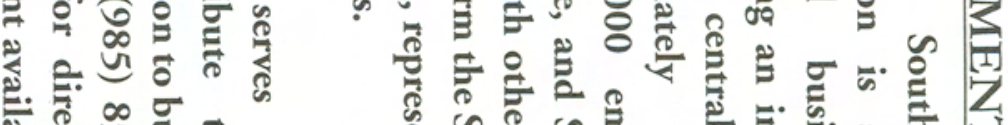

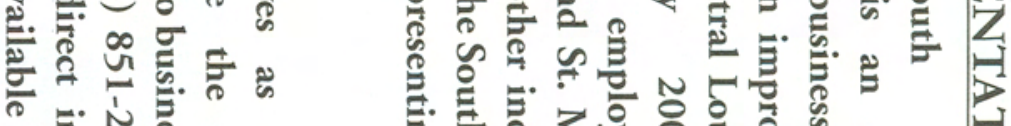

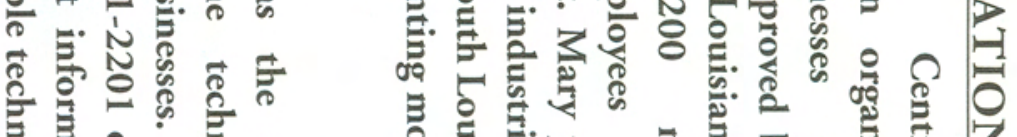

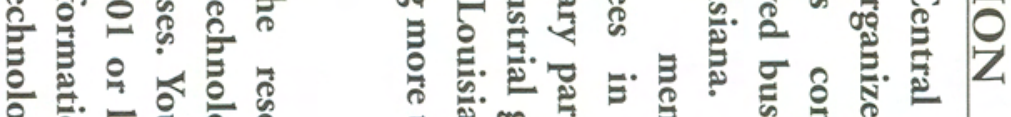
。․ำ.

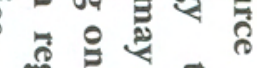

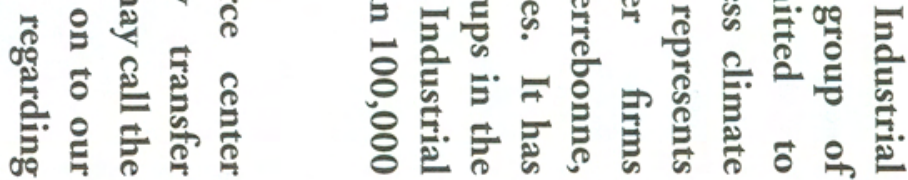

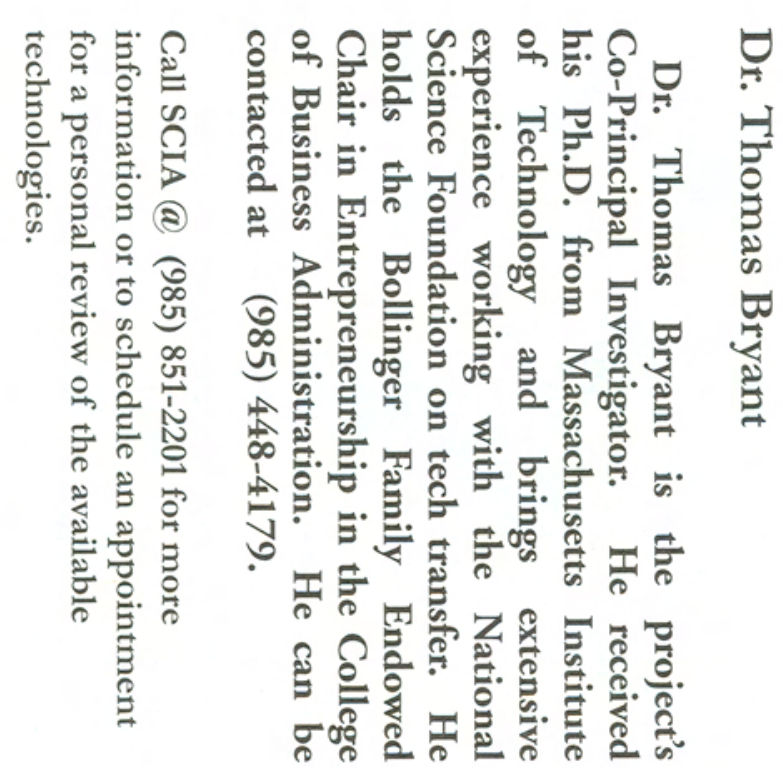

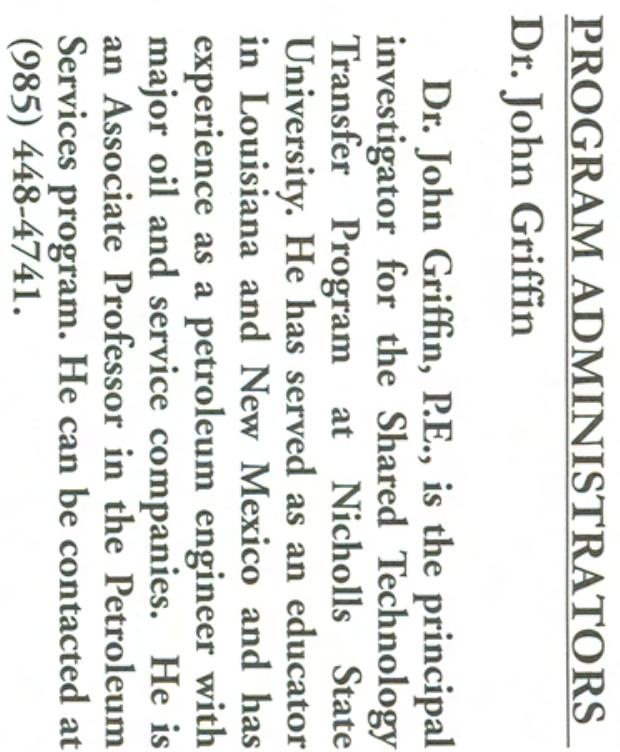


Appendix G 


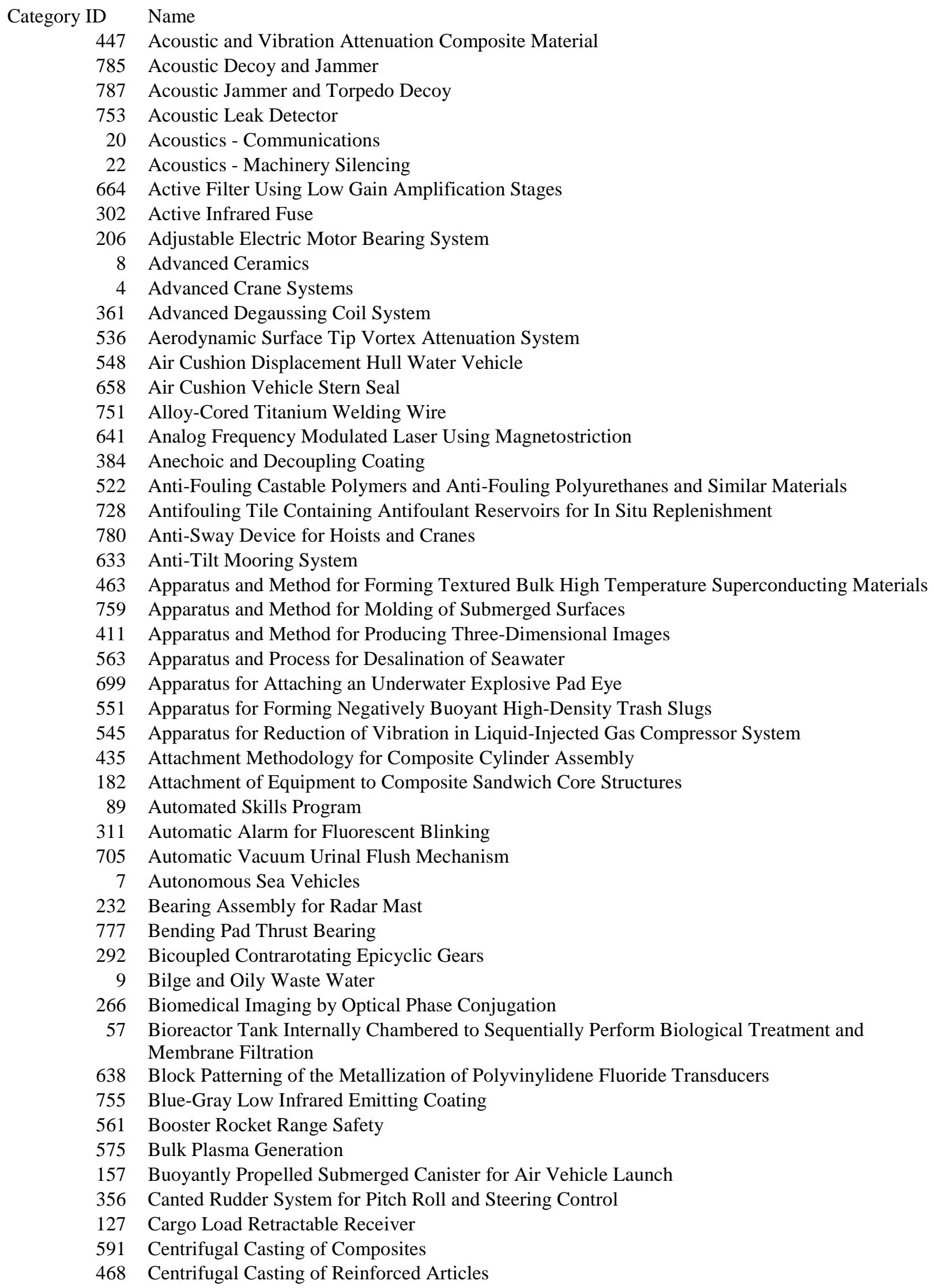


138 Centrifugal Compressor with Vaneless Diffuser

740 Centrifugal Pump Recirculation Diffuser

663 Centrifugal Scavenging System for Single Screw Compressors

268 Ceramic Mass Loaded Longitudinal Vibrator

301 Ceramic Material

419 Chromic Oxide Coatings by Thermal Decomposition of Chromic Acid Anhydride (CRO3)

669 Chromium Based Corrosion Resistant Hard-Facing Alloy

716 Closed Cycle Vaporization Cooling System for Underwater Vehicle Inner-To-Outer Hull Heat Transfer

273 Coating Evaluation System

474 Combined Bulbous Bow and Sonar Dome for a Vessel

622 Combined Limiting/AGC IF System

596 Combined Mine Safety Deployment and Activation System

203 Combined Wedge-Flap for Improved Ship Powering

31 Communications - Sensors

29 Communications - Wireless Communications

365 Compact Water Jet Propulsion System for a Marine Vehicle

540 Compact, Two-Speed, Reversible Drive Mechanism

193 Component Deployment Means for Ice Penetrating Acoustics Communication Relay System

519 Composite for Making Superconducting Wires or Tapes

36 Composite Materials - Applications

35 Composite Materials - Fabrication Methods

34 Composite Materials - Materials

413 Composite Structure Forming a Wear Surface

470 Composite Structures Having Organic Matrices and Duplex Zinc/Ceramic Fire Barriers

106 Composite Vibration Damping System

146 Composite Water-Tight Door Panel Installation

354 Compress/Melt Processor for Contaminated Plastic Waste

679 Compressor-Scavenging Eductor System

6 Computational Fluid Dynamics

219 Concentration of Isotropic Hydrogen by Temperature Gradient Effect in Soluble Metal

252 Contamination Control of Emission Discharge

49 Contour Stern Flap

170 Control Tab Assisted Lift Reducing System for Underwater Hydrofoil Surface

604 Convectively Cooled Hot Gas Exhaust Structure to Reduce Infrared Radiation

737 Conversion Between Magnetic Energy and Mechanical Energy

278 Conveyor Safety Tray

92 Cooled Jet Blast Deflectors for Aircraft Carrier Flight Decks

766 Copper Base Antifouling Paints with PH Control

34 Corrosion Resistant Coating

624 Corrosion Resistant Metallic Glass Coatings

455 Corrosion Resistant Shell and Tube Heat Exchanger and a Method of Repairing the Same

213 Corrosion-Resistant Coating Prepared by the Thermal Decomposition of Lithium Permanganate

425 Coupling Stud Assembly

747 Crack Susceptibility Test Utilizing an Airport Restraint Specimen

$313 \mathrm{CrB} 2 . \mathrm{MbB} 2 / \mathrm{Al} 2 \mathrm{O} 3$ and $\mathrm{CrB} 2 . \mathrm{NbB} 2 / \mathrm{SiC}$ Ceramic Composite Materials

437 Credential Tracking System

271 Dark Coating with Low Solar Infrared Absorbing Properties

50 Deck Drain Cover Plate Assembly

240 Desensitized Firing Circuit

387 Design of an Integrated Inlet Duct for Efficient Fluid Transmission

5 Design, Evaluation \& Ship Performance 
405 Detection of Buried Nitrogen Rich Materials

410 Detection of Radar Targets Using Higher-Order Statistics

37 Devices

41 Devices - Bearings

39 Devices - Electrical

38 Devices - Mechanical

42 Devices - Pipes, Valves, Drains

40 Devices - Seals

211 Diagonal Hatch System for Ships

580 Differential Pressure Sensor

611 Diffusion Bonding Process for Aluminum and Aluminum Alloys

500 Digital Reverberation Time Measurement System

309 Digital Simulations of Organismal Growth

706 Direct Open Loop Rankine Engine System and Method of Operating Same

786 Discharge and Pressure Relief Ports for Mechanisms with Involute Shaped Vanes

298 Discriminate Reduction Data Processing

310 Discriminate Reduction Data Processor

307 Disposal of Oil Spill Cleanup Collections

336 Drag Reducing Rapid Solvating Slurry Concentrate and Preparation

710 Dual Capability Piezoelectric Shaker

599 Dual Demodulating Circuit Tracer

738 Dual Dependent Stores Ejector Assembly for Angular Rate and Position Control

338 Dualcavitating Hydrofoil Structures

316 Dualcavitating Hydrofoil Structures for Multi-Speed Applications

276 Duct Flow Control System

218 Duel Energy Dependent Fluids

460 Duplex Rolling Element Bearing Mounting for Ensuring Preload Control

175 Dynamic Ramp Interface System

573 Early Ballistic Missile Detection System

621 ECM Simulator for Missile Fire Control System Vulnerability Studies

118 Efficiency Maximized Conversion of Electrical to Mechanical Energy by Magnetostrictive Transduction

103 Efficient Use of Metallic Materials for Dynamic Tear Testing

254 Elastomeric Cartridges for Attenuation of Bearing-Generated Vibration in Electric Motors

201 Elastomeric Composite Bumper System and Method for Absorbing High Energy Impact

649 Elastomeric Mount for Thrust Bearing Shoe

258 Electric Field Control of Epiletiform Activity

657 Electric Wave Device and Method for Efficient Excitation of a Dielectric Rod

43 Electric Wet Connectors

44 Electric Wet Connectors - Fiber Optic Connector

734 Electrical Actuator for Ship Roll Stabilization

79 Electrical Current Transferring and Brush Pressure Exerting Spring Device

752 Electrical Energy Storage Type Filter

510 Electrical Firing Circuit

205 Electrochemical Fabrication of Capacitors

648 Electrochemical Preparation of Silver Oxide Electrodes Having High Thermal Stability

215 Electrolytic Disinfectant System

171 Electromagnetic Sea Mine Detonation System

471 Electron Acceleration System

350 Electronic Primer Ignition System

490 Electro-Rheological Control Valve

530 Electro-Rheological Disk Pump 
230 Electro-Rheological Fluid Composition Having Polymeric Sponge Particularates

35 Embedded Wear Sensor

195 Embedded Wear Sensor

141 Emergency Landing Impact Absorbing System for Aircraft

163 Emergency Ship Towing System

45 Environmental Protection

46 Environmental Protection - Machinery

47 Environmental Protection - Testing

133 Exhaust Blockage System for Engine Shut Down

174 Explosive Containment Device

678 Fabrication of Hollow, Cored, and Composite Shaped Parts from Selected Alloy Powders

188 Fabrication of Metal-Matrix Compositions

191 Fabrication of Tile Reinforced Composite Armor Casting

795 Faired Tow Cable with Stubs for Strum Reduction

48 Fatigue and Crack Growth

21 Fatigue and Crack Growth

366 Fiber Optic Loose Tube Buffer to Fan-Out Tube Adapter System

359 Fire Detection and Extinguishment System

331 Fire Detector

458 Fire Protective Coating and Method for Applying Same to a Structure

478 Fireproof Barrier System for Composite Structure

494 Fire-Resistant Barriers for Composite Materials

655 Flexible Extendable Backing Shield for Welding Reactive Metals

464 Flexible High Damping Structure

274 Flexible High-Damping Composite Structures and Fabrication Thereof

632 Flexible Mine Case

691 Flexible Trailing Shield for Welding Reactive Metals

109 Flight Deck Handling System for Landed Aircraft

87 Floating Oil Boom Cleaning Apparatus

444 Floating Platform Tow Post

122 Flow Control System for a Forced Recirculation Boiler

263 Flow Energizing System for Turbomachinery

700 Fluid Equalized Tilting Pad Thrust Bearings

750 Fluid Lubricated Floating Bushing Seal

687 Fluid Sampler

151 Fluidborne Sound Projector

58 Fluidborne Sound Projector with Sweep Cleaning Facilities

779 Fluidic Controlled Diffusers for Turbopumps

335 Fluidtight Door Gasket

125 Fluxgate Magnetic Field Sensor Incorporating Ferromagnetic Test Material into its Magnetic Circuitry

200 Foil Assisted Marine Towing

330 Formulations and Preparation of a Gel System for the Promotion of Rapid Solvation in Aqueous Systems

778 Friction Reducing Arrangement for Hydraulic Machines

24 Fuel Cell Laboratory

19 Fuel Cells

196 Fuel Storing Water Ballast Tank Internally Structured for Reducing Retention of Water and Overboard Discharge of Fuel

112 Gas Turbine Engine System with Water Injection

41 Geometrical Modeling of Structural Products

67 Gradiometric Measurement Methodology for Determining Magnetic Fields of Large Objects 
42 Grapple Anchor Device for Underwater Towing of Watercraft

236 Guidance Information Analyzer

326 Guided Wing for Aircraft Flying at High Angles of Attack

296 Hand Held Vacuum Heat Sealer Apparatus

640 Heat Engine Based on Shape Memory Alloys

600 Heat Engine with Corrugated Shape Memory Drive Belt

332 High Concentration Slurry-Formulation and Application

562 High Damping Flexible Propeller/Impeller

104 High Energy Impact Absorption Fender System Using Valvular Control Logic

553 High Power Microwave Generator

739 High Pressure Electrolytic Oxygen Generator

499 High Pressure Pump for Electro-Rheological Fluids

609 High Pressure Single Screw Compressors

396 High Pressure Slab Motor

84 High Speed Drag Reducing Ventilation for Marine Vessel Hulls

284 High Speed Magnetostrictive Linear Motor

583 High Torque Magnetic Angular Positioning Motor

654 High Voltage Impulse Wave Generator for Testing Equipment

37 High-Damping Composite Structures

297 High-Energy-Absorbing Enclosure for Internal Explosion Containment

680 High-Speed Towline

251 Homopolar Transformer for Conversion of Electrical Energy

77 HTS Film-Based Electronic Device Characterized by Low ELF and White Noise

321 Hull Supported Steering and Reversing Gear for Large Waterjets

323 Hybrid Framing System for Vessels

116 Hybrid Hull Construction for Marine Vessels

508 Hybrid Hydrofoil Interface with Wet Well Deck

481 Hybrid Hydrofoil Strut Leading Edge Extension

63 Hybrid Linear Motor

527 Hydraulic Pump with Integral Electric Motor

69 Hydrodynamic and Supportive Structure for Gated Ship Stern

765 Hydrodynamic Bearing with Extended Pressure Gradient

119 Hydrodynamic Propulsion Flow Control for Modification of Flap Controlled Lift

49 Hydrodynamics

50 Hydrodynamics - Hull Forms

51 Hydrodynamics - Other Fluid Dynamics

52 Hydrogen Technologies

668 Hydrostatic Supporting Device

154 Hysteresis Reduction in Giant Magnetostrictive Materials

438 Impeller Assembly for Processing Device

420 Infeed Hopper with Pivotable Throat for Shredder or Granulator

111 Inflatable Vibration Reducing Fairing

390 Infrared Decoy

732 Inrush Current Limiter

18 Integrated Condition Assessment

291 Integrated Electrical Power Supply System for Propulsion and Service Control

744 Integrated Faired Towline with Integral Locking Feature

741 Integrated Fire-Resistant Flexible Metal Conductor Derived Insulated Coating

173 Integrated Liquid Discharge System

159 Integrating Fluxgate Magnetometer

637 Integrator and Firing Circuit for Proximity Fuses

221 Intermittent Programming of Electrosettable Compositions 
493 Interpenetrating Polymer Network Acoustic Damping Material

681 Interpenetrating-Network Polymeric Electrolytes

773 Interplaner Hinge Joint for SES Seals

776 Isolated Reverse Turbine System for Gas Turbine Engines

147 Landing Impact Absorbing Deployment System for Aircraft with Damaged Landing Gear

364 Large Scale Purification of Contaminated Air

144 Laser Irradiation Induced Non-Skid Surface Layer Formation on Substrate

725 Laser Pumped Superconductive Energy Storage System

485 Laser Resistant Optical Detector Arrangement

721 Leading Edge Augmentor Wing-In-Ground Effect Vehicle

636 Leakage Path Interconnection for Single Screw Mechanisms

102 Leakage Plugging Method and Implement

428 Lightweight Battery Electrode and Method of Making It

369 Lightweight Zinc Electrode

64 Linear Magnetostrictive Actuator

275 Lip and Cheek Retractor

690 Liquid Metal Brush Material for Electrical Machinery Systems

629 Load Bearing Connective Damper

357 Load Limit System for Mechanical Linear Actuator

97 Load Transporting Modular Platform System

150 Load-Saving Multi-Axis Connector

53 Logistics

54 Logistics - Programs

55 Logistics - Systems

453 Low Flow Fluid Separator

643 Low Power Liquid Crystal Display Backlight

54 Low Solar Absorbing Nonskid Composition and Application Configuration for a Flight Deck

424 Low Vibration Polymeric Composite Engine

656 Low-Cost, Expendable, Crushable Target Aircraft

17 Machinery Design Optimization

666 Magnetomechanical Energy Conversion

377 Magnetostrictive Actuator with Auxiliary Leakage Reducing Magnetic Bias

156 Magnetostrictive Actuator with Load Compensating Operation Modification

101 Magnetostrictive Adjustment of Propeller Blade

585 Magnetostrictive Linear Motor

132 Magnetostrictive Magnetically Controlled Sprag Locking Motor

461 Magnetostrictive Torque Sensor

452 Malone-Brayton Cycle Engine/Heat Pump

166 Manufacture of Nitinol Rings for Thermally Responsive Control of Casing Latch

619 Marine Mine Fire Control Mechanism

371 Marine Propeller

488 Marine Propulsion Unit with Controlled Cyclic and Collective Blade Pitch

550 Mass Loaded Composite Rotor for Vibro-Acoustic Application

707 Mastless Sails

552 Material and Method for Fast Generation of Hydrogen Gas and Steam

731 Mechanical Actuation Device for Ship Roll Stabilization

720 Mechanical Clutch/Decoupler for Hydraulic Pumps

570 Mechanical Scavenging System for Single Screw Compressors

516 Mechanical Shielding for Electric Primer

712 Mechanism for Proportionately Loading Dual Thrust Bearing Assemblies Against Axial Thrust Loads

564 Membrane Perfusion Method and Apparatus for Determining Dose Response Relationships for 
Soluble Biologically Active Chemical Agents Released from a Surface

538

639

246

14

577

56

60

59

58

57

312

123

315

300

243

308

788

459

797

379

503

262

115

403

480

565

549

487

194

473

451

394

117

322

255

628

760

208

535

66

556

676

318

227

320

235

239

145

Metal Alloy and Method of Preparation Thereof

Metal Film Coatings on Amorphous Metallic Alloys

Metal Matricies Reinforced with Silver Coated Boron Carbide Particles

Metal Matrix Composites

Metal Oxide Modification for Use in Protective Coatings

Metallurgy

Metallurgy - Applications

Metallurgy - Corrosion Prevention

Metallurgy - Fabrication Methods

Metallurgy - Materials and Alloys

Metering System for Compressible Fluids

Method and Apparatus for a Reduced Parts-Counts Multilevel Rectifier

Method and Apparatus for Generating Fingerprints and Other Skin Prints

Method and Apparatus for Heated, Pressure-Swing High Pressure Air Dehydration

Method and Apparatus for Inducing Fully-Reversed Three-Dimensional Loading on a Non-

Rotating Beam

Method and Apparatus for Measuring the Depth of an Underwater Target

Method and Apparatus for Molding and Replicating Minute Surface Characteristics

Method and Apparatus for Reducing Axial Thrust in Centrifugal Pumps

Method and Apparatus of Testing a Model

Method for Improving the Performance of Underwater Explosive Warheads

Method for In-Situ Casting of Fire Barrier Silicone Sheets Onto Acoustic Tiles

Method for Launching Projectiles with Hydrogen Gas

Method for Measuring Vorticity

Method for Processing Contaminated Plastic Waste

Method for Producing Closed Cell Spherical Porosity in Spray Formed Metals

Method of Bonding Carbon-Carbon and Metal Matrix Composite Structures

Method of Bonding Metal Carbides in Non-Magnetic Alloy Matrix

Method of Bonding Molybdenum to Steel

Method of Centrifugally Casting Reinforced Composite Articles

Method of Lowering the Reaction Exotherm in Thermally Polymerized Acetylene Terminated

Resins

Method of Making a Photodetector Array Having High Pixel Density

Method of Making Ultrahigh Density Charge Transfer Device

Method of Manufacturing Rein Infused Core Structure

Method of Measuring the Thermals Conductivity of Microscopic Graphite Fibers

Method of Protecting a Structure

Method of Soldering Aluminum

Method of Suppressing Radiation from Ship Stack Gases

Method of Suppressing Thermite Reactions in Plasma Arc Waste Destruction System

Method to Produce Ceramic Superconducting Filaments Bonded to Metals

Method, Apparatus and Control Logic for Damage Reconfiguration of an Electro-Mechanical

System

Microchannel Electron Source

Millimeter Wavelentgh Dielectric Waveguide Having Increased Power Output and a Method of Making Same

Mine Sweeping System for Magnetic and Non-magnetic Mines

Miniature, Low Power, Electromechanical Safety and Arming Device

Miniature, Low-Power Electromechanical Safety \& Arming Device

Missile Altitude Safing System

Missile Safety System for Assuring Minimum Safe Distance

Modular Bulwark Deck Shielding Construction and Assemblage 
456 Modular Hydraulic Control System

72 Modular Multifunction Vehicle Interface System

40 Monitoring of Aircraft Usage

237 Monitoring Safety System

48 Monitoring Waste Liquid to Determine Membrane Cleansing Performance

735 Mono-Element Combined Supercritical High Lift Airfoil

61 Mooring and Lifting

63 Mooring and Lifting - Fendering

62 Mooring and Lifting - Mooring and Lifting Lines

742 Motor/Generator Armature Portable Baking Oven

644 Mullite Whisker Preparation

179 Multiassay Method for Determining the Concentrations of Antigens and Interferants

343 Multi-Cycle Electric Motor System

484 Multifilamentary Superconducting Cable and a Method of Manufacturing It

504 Multifunction Hydrodynamic and Buoyant Hull Extension for Planing Water Craft

439 Multi-Layered Translated Rib-Stiffened Composite Hollow Cylinder Assembly

660 Multiple Tooth Engagement Single Screw Mechanism

225 Multi-Ported Diverter Valve Assembly

401 Multistage Fluid Flow Control Device

375 Multi-Stage Fluid Flow Control Device

400 Multistage Variable Throttle Valve

140 Neural Network System for Estimating Surfaces of Seawater Vessels

686 Nickel Oxide, Ceramic Insulated, High Temperature Coating

280 Non-Aqueous Lithium Cells

667 Non-Aqueous Primary Cell

389 Non-Contacting Capacitance Probe for Dielectric Cure Monitoring

131 Nondestructive Detection of Steel Surface Corrosion

11 Non-Destructive Evaluation

38 Non-Invasive Pressure Measurement in Pipes

295 Non-Pulpables Collection Chamber with Removable Basket for Solid Waste Pulpers

587 Non-Volatile Memory Cell with Ferroelectric Capacitor Having Logically Inactive Electrode

682 Oil Content Monitor/Control System

363 Oil Spillage Detector

75 Oil Water Separator with Air Sparging Array for In-Situ Cleaning

685 Oil/Water Disperser Device for Use in an Oil Content Monitor/Control System

223 Oily Waste Water Treatment

265 Omnidirectional and Controllable Wing Using Fluid Ejection

528 Operating at Sea Island Station

642 Optical Phase Conjugate Beam Modulator and Method Therefor

756 Optimized Diesel Engine Exhaust Silencer

652 Opto-Optical Beam Deflector, Modulator, and Shaper

214 Organic Waste Disposal System

746 Organotin Antifouling Coating with Epoxy and Polyacrylate Compositions

713 Organotin Antifouling Coatings with Novolac and Bisphenol-A Epoxy Resins

491 Oscillatory Abrasive Cable Power Saw

64 Other

98 Overboard Rescue System

78 Oxidation Resistant Coating for Carbon

33 Paints and Coatings-General

718 Paravane with Automatic Depth Control

257 Passive Piezoelectric Prosthesis for the Inner Ear

245 Patterning Antibodies on a Surface 
560 Payout Tension Control System for Reel Mounted Cable

477 Pendulum Based Power Supply for Projectiles

653 Phase Control Mechanism for Wave Energy Conversion

769 Piezoelectric Polymer Antifouling Coating

762 Piezoelectric Polymer Antifouling Coating and Method of Use and Application

39 Plastic Waste Disposal

715 Platinum Underlayers and Overlayers for Coatings

100 Polymer Having Network Structure

65 Polymers

68 Polymers - Applications

67 Polymers - Fabrication Methods

66 Polymers - Materials

770 Polysobutylene Rubber Antifouling Paint

47 Polyurethane Electrostriction

450 Polyurethane-Acrylic Interpenetrating Polymer Network Acoustic Damping Material

448 Polyurethane-Epoxy Interpenetrating Polymer Network Acoustic Damping Material

768 Porous Interface Stabilized Liquid Metal Current Collector

53 Power Frequency Electromagnetic Field Compensation System

333 Power Plant Simulation for Waterborne Vessel Computer-Assisted Design and Evaluation

20 Power Systems Modeling

711 Pressure Balanced Floating Seal

352 Pressure Cast Alumina Tile Reinforced Aluminum Alloy Armor and Process for Producing the Same

772 Pressure Compensated Potable Water Chlorinator

799 Pressure Plate Mine Sweep

186 Prestress Imposing Treatment of Magnetostrictive Material

496 Process for Forming Articles with Anisotropic Properties

422 Process for Preparing Microcapsules Having Gelatin Walls Crosslinked with Quinone

432 Process for Producing Hydrophilic Polymer Membranes

576 Process for Producing Uniform Protective Coating of Silver Metal on Carbon/Carbon Composites

523 Process for Shaping Articles from Electrosetting Compositions

514 Process of Shaping an Electrorheological Solid

61 Processing of Shipboard Wastewater

178 Processing Treatment of Amorphous Magnetostrictive Wires

349 Programmable Electroset Processes

162 Programmed Computation of Predicted Loading of Ship Hull

95 Programmed Logistic System and Method for Transportation and Reception of Commodities

176 Propelled Cable Fairing

590 Propeller Unit with Controlled Cyclic and Collective Blade Pitch

124 Propulsion Nacelle Alignment System for Tilt-Rotor Aircraft

416 Protective Device for Container

134 Protective Enclosure with Peripheral Fluid Storage Facility

88 Protective Fendering System for Off-Shore Cargo Transferring Surface Ships

184 Protective Shrouding with Debris Diverting Inflow Vanes for Pumpjet Propulsion Unit

346 Pulsating Behavior Monitoring and Modification System for Neural Networks

314 Pulse Controlled Motion Conversion System for Magnetostrictive Motor

618 Pulsed Laser Beam Deviation Apparatus

789 Pump Piston with Flexible Member

543 Pyrite Cathode Material for a Thermal Battery

423 Pyronol Torch

136 Quiet and Efficient High-Pressure Fan Assembly

763 Quiet Impulse Steam Trap 
Radar Reflecting Rescue Device

142 Radar Tank Level Indicating System for Measurement of Water Content in Shipboard Tank Involving Identification of Fuel-Water Interface

757 Rare Earth-Iron Magnetostrictive Materials and Devices Using These Materials

445 Real Time Cardiac Arrhythmia Stabilizing System

382 Real Time Stabilizing System for Pulsating Activity

290 Regulated Dispensing System

546 Remotely Settable Multi-Output Electronic Time Fuse and Method of Operation

264 Resistive Wall Klystron Amplifier Having Grounded Drift Tube

671 Retractable, Lever Action, Scroll Seal for a Surface Effect Ship

421 Retrofittable Monolithic Box Beam Composite Hull System

651 Rigid Support Structure for Single Screw Compressors

693 Rocket-Powered Training Missile with Impact Motor Splitting Device

319 Rotary Compressor with Pulsation Minimizing Discharge

489 Rotary Hydraulic Servo or Throttle Valve

376 Rudder for Reduced Cavitation

192 Rudder Tab for Suppression of Tip Vortex Cavitation

69 Safety

661 Safety Cathode for Non-Aqueous Electrochemical Cell

355 Safety Latch

631 Safety-Arming System for Launched Projectiles

83 SCUBA Diver Fairing

44 Seal Compression Indication System

677 Seal for Air Cushion Vehicle

70 Security Systems

279 Selectively Controlled Electrical Power Switching System

748 Self-Aligning Contact Thrust Bearing/Vibration Reducer Element

483 Self-Contained System for Surface Ship Protection Against Moored Contact Mines

761 Self-Powered Vehicle Detection System

758 Semi-Tandem Marine Propeller

202 Shape Memory Actuator System

294 Shielded Bearing Lubrication

803 Ship Force Protection

736 Ship Roll Stabilization System

507 Ship Wake Vorticity Suppressor

790 Shipboard Blackwater Physical/Chemical Treatment System

187 Shipboard Paint Dispensing System

555 Shipboard Sensor Exerciser Apparatus

137 Shipboard System for Furnishing Information on Mine Threat Vulnerability

783 Shock Crush Sub-Foundation

774 Shock-Crush Subfoundation

340 Si3N4 Reinforced Monoclinic BaO.Al2O3.2SiO2 and SrO. Al2O3.2SiO2 Ceramic Composites

517 Silver Lined Ceramic Vessel

582 Silver-Nickel Composite Cathodes for Alkaline Secondary Batteries

557 Single Screw Interrupted Thread Positive Displacement Mechanism

139 Sintered Viscoelastic Particle Vibration Damping Treatment

160 Skidplate Having Non-Symmetrical Hydrofoil Profiles Producing Skid-Opposing Side Force Only During Turn Maneuver

13 Smart Ship Technology

598 Smokestack Having Reduced IR Emission

698 Solar Breeze Power Package and Saucer Ship

436 Solid Particle Contaminant Detection and Analysis System 
589 Solid State Modulator for Microwave Transmitters

804 Solid Waste Disposal

805 Solid Waste Disposal

806 Solid Waste Disposal

372 Solid Waste Pulper

674 Solid-State Photometer Circuit

541 Sound Absorbing Muffler

128 Spatially Integrating Fluxgate Magnetometer Having a Flexible Magnetic Core

256 Spinning Filter Separation System for Oil Spill Clean-Up Operation

130 Split Face Mechanical Seal System

86 Stabilized Tumblehome Hull Form

143 Standing Wave Magnetometer

181 Steering and Backing Systems for Waterjet Craft with Underwater Discharge

93 Stern Depressor Type Motion Stabilization System for Marine Vessel

60 Stern Flap Corrective Motion and Fuel Saving Control System

317 Strain Sensing System Including a Magnetostrictive Material Having a Piezomatic Property Selected for Maximizing Electrical Impedance to Current Applied to A Predetermined Skin Depth

467 Stratified Carrier Electroviscous Fluids and Apparatus

743 Structural Damper for Eliminating Wind Induced Vibrations

28 Structural Evaluation Laboratory

475 Submarine Mast Fairing Bearing Configuration

16 Subsea Acoustic Transmission

342 Subsurface Examination of Non-Ferrous Material for Detecting Corrosion by Measuring Magnetic Traction

796 Supercavitating Propeller with Air Ventilation

486 Superconducting Fibers Made with Yttrium and Yttrium Oxide Interlayers and Barium Cuprate Cover Layers

135 Superelastic Sealing Closures

745 Superior Ohmic Contacts to III-V Semiconductor by Virtue of Double Donor Impurity

767 Supported Membrane Planer for SES Seals

259 Suppression of Epileptiform Activity

791 Surface Effect Ship Internal Sidewall Drag Reduction Device

341 Surge Voltage Generator for Pulsing Grounded and Ungrounded Electrical Equipment

55 Synthesis of Li2Mn4O9 Using Lithium Permanganate Precursor

189 Synthesis of Metal Matrix Composite

617 System for Control of Weld Arc Development

180 System for Detection of Flaws by Use of Microwave Radiation

247 System for Focused Generation of Pressure by Bubble Formation and Collapse

386 System for Monitoring and Analyzing Field Energy Exposure

304 System for Preventing Biofouling of Surfaces Exposed to Water

158 Tailorable Elastomeric Composite Pneumatic Fender System for Absorbing High Energy Impact

216 Tapered Resilient Sleeve Bearing Assembly

404 Target Camouflaging Chaff Dispenser with Ejectable Closure

524 Techniques for Preparation of Ingot Metallurgical Discontinuous Composites

71 Techniques/Processes

72 Techniques/Processes - Chemical Process

73 Techniques/Processes - Inspection/Maintenance Techniques

74 Techniques/Processes - Instrumentation

161 Tensile Specimen Test Grip

646 Terbium-Dysprosium Magnetostrictive High Power Transducers

288 Terbium-Dysprosium-Zinc and Terbium-Gadolinium-Zinc Magnetostrictive Materials and Devices

662 Test Rig for Examining Seal Finger Wear 
164 Thickness Determination of Carbonaceous Overlayers on Substrates of Differing Material

717 Thrust Deflector and Force Augmentor

525 Thrust Expansion Engine

782 Thyristor Firing Circuit Module with Integral Optical Isolation, DV/DT Limitation, and Bidirectional Voltage Transient Suppression

673 Tilt-Rotor Wing Fold Mechanism and Method

114 Time-Frequency Dependent Damping via Hilbert Damping Spectrum

431 Titanium Alloy Containing, Al, V, Mo, Fe, and Oxygen for Plate Applications

771 Torpedo Guards

383 Torque Balanced Postswirl Propulsor Unit and Method for Eliminating Torque on a Body

495 Towed Submergible, Collapsible, Steerable Tank

595 Toxin Containing Perforated Antifouling Polymer Nozzle Grommet

305 Tractor Podded Propulsor for Surface Ships

764 Transcavitating Propeller

798 Transformer Movable Along Power Cable

581 Transition Radiation Interference Spectrometer

703 Transverse Waterjet Propulsion with Auxiliary Inlets and Impellers

505 Tunable Laser Frequency Stabilizing System

402 Twisted Rudder for a Vessel

15 Twisted Rudders

393 Two Electrode Device for Determining Electrical Properties of a Material on a Metal Substratum

289 Two Phase HfB2-SiB2 Material

152 Ultra Low Carbon Bainitic Weathering Steel

207 Ultrahigh Density Charge Transfer Device

56 Underwater Detection and Deterrent System

107 Underwater Explosion Protection for Watercraft

688 Underwater Formulation and Method for Cleaning and Waxing Simultaneously

3 Underwater Hull Husbandry Robot

62 Underwater Target Testing

129 Underwater Towing of Marine Vessels

281 Unmanned Sea Surface Vehicle Having a Personal Watercraft Hull Form

43 Unmanned Watercraft Retrieval System

515 Variable Breadth Impeller that Provides a Specific Shutoff Head

692 Variable Camber Tandem Blade Row for Turbomachines

659 Variable Capacity Centrifugal Pump

492 Variable Draft Hull

238 Variable Range Timer Impact Safety System

727 Variable Wing Position Supersonic Biplane

220 Vectored Propulsion System for Sea-Going Vessels

172 Vehicle Presence, Speed and Length Detecting System and Roadway Installed Detector Therefore

199 Ventilated Outboard Motor-Mounted Pumpjet Assembly

253 Venturi Muffler with Variable Throat Area

398 Vessel with Machinery Modules Outside of Watertight Hull

512 Vessel-Capturing Berthing Facility Incorporating Relative Motion-Mitigating Apparatus

670 Vibration and Shock Resistant Heat Exchanger

794 Vibration Isolator and Method for Manufacturing Same

625 Vibration Reducing Thrust Bearing

293 Vibration-Damping of Structural Products

70 Visual-Tactile Sinage

414 Voltage Surge Suppression Power Circuits

77 Vortex Induced Vibration 
80 Vortex Induced Vibration - Facilities

79 Vortex Induced Vibration - Predictive Techniques

78 Vortex Induced Vibration - Vibration Control Devices and Techniques

378 Warhead Influence

212 Waste Aerosol Container Processor

358 Water Ablative Coating for Drag Reduction Applications

334 Water Ablative Coating for Vehicle Drag Reduction

51 Watertight Door Closure

531 Wave Cancellation Multihull Ship

697 Weld Metal Cooling Rate Indicator System

373 Zero Field Degaussing System and Method 


\section{Appendix H}


\#086

FOR IMMEDIATE RELEASE (also located at : http://www. nicholls.edu/news/2005/086.html)

Contact: Michael J. Delaune or Lydia Boudreaux

$(985) 448-4143$

April 19, 2005

\section{NICHOLLS AND SCIA TEAM UP TO PROVIDE TECHNOLOGY FOR SMALL BUSINESSES}

THIBODAUX - Local businesses will have access to technologies developed by the U.S. Navy with the help of a pilot program announced Tuesday by Nicholls State University and the South Central Industrial Association.

The Shared Technology Transfers program is designed to educate members of the private sector about the vast technology resources previously available only to the U.S. Navy and its contracted partners. Nicholls and SCTA are working with the Houston Advanced Research Center and the Carderock Division of Naval Sea Systems Command to catalog more than 600 unclassified patents and provide them online, complete with descriptions and test summarics.

Dr. John Griflin, an associate professor of petroleum services and head of the project at Nicholls, said, "Some of the large-scale companies have access to this knowledge, but there's been no conduit for the smaller businesses. That's what we're doing. We're trying to help the small businesses of south Louisiana compete on a national scale. If even one business in the tri-parish area can find a technology that will help it grow,

then this project will be a success." Griffin and Dr. Thomas Bryant, the Bollinger Family Endowed Chair in Entrepreneurship, are administering the program at Nicholls.

The datahank will include technologies for hydrogen extraction from seawater, methane hydrate processing, carbon sequestration, extremely high pressure valves and seals, sensors and monitoring systems and advanced power sources like fuel cells for marine application. SCIA will serve as

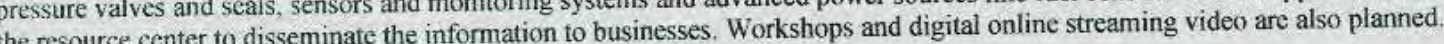

SCIA executive director Jane Amette said, "This is a great opportunity for industry, both current and future, in south Louisiana. The available technology transfers are a perfect way to enhance economic development for the area. SCIA is pleased it can assist Nicholls with distributing this information through our membership, industrial coalition group and our website."

The pilot program is funded by a U.S. Department of Energy grant totaling nearly \$I million.

For more information about the Shared Technology Transfers program at Nicholls State University, visit hitp:/www micholls edu/sitp or hito:/ www scracnline net or call the South Central Industrial Association at (985) 851-2201. 
ADVOCATE

Baton Rouge, LA

Daily \& Sunday

(Dly 101,786: Sun 134.953)

May 1, 2005

Technology transfers 64

Local businesses now have access to technologies developed by the Navy through a pilot program announced by Nicholls State Universi ty and the South Central Industrial Association.

The Shared Technology Transfers program educates the private sector about technology resources previously available only to the Navy and its contract partners. Nicholls and SCIA are working with the Houston Advanced Research Center and the Carderock Division of Naval Sea Systems Command provide online more than 600 unclassified patents.

The databank will include technologies for hydrogen extraction from seawater; methane hydrate processing; carbon sequestration; high-pressure valves and seals; sensors and monitoring systems; and advanced power sources.

For more information, visit http:/www.nicholls.edu/sttp or $\mathrm{http} J / \mathrm{www}$.sciaonline.net or call the South Central industrial Association at (985) 851-2201. 


\section{Wednesday, May 4, 2005

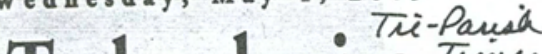 Technologies open to local businesses}

BY KENNY BOUDREAUX Tri-Parish Times

T T igh-powered fuel cells for years have been used to increase fuel efficiency and 11 increase fuel efficience used in conjunction with gas turbine generators to more efficiently distribute power and reduce fuel consumption. The results: significant cost savings.

But most companies in the Louisiana maritime and offshore industries couldn't order the device or get research conducted on the equipment. Now they can access it along with hundreds of other hidden technologies and studies.

Officials with the South Central

Industrial Association (SCIA) and Nicholls State University have teamed up to compile a list of more than 600 unclassified patents and provide them online, complete with descriptions and test summaries. The technologies now available at ww w s ciaonline.net and www.nicholls.edu/sttp for local businesses had only been used by the U.S. Navy and its contractors.
Jome of the large-scale companies have access to this knowledge, but there's been no conduit for the smaller businesses," explains Dr. John Griffen, an associate professor of petroleum services and head of the project at Nicholls. "That's what we're doing. We're trying to help the small businesses of South Louisiana compete on a national scale."

The Shared Technologies Program, as it is known, is designed to educate members of the private sector about the vast technology resources previously available only for government use. Nicholls and SCIA are also working with Houston Advanced Research Center and Carderock Division of Naval Sea Systems Command'on the $\$ 1$ million program, funded by the U.S. Department of Energy.

Griffen and Dr. Thomas Bryant, a Nicholls professor who holds the Bollinger Family Endowed Chair in Entrepreneurship, are administering the program at Nicholls. Though NASA has been able to release some of its technologies for the aerial industry, Griffen says no federal agency has ever shared such information with the maritime industry until now.

Some of the technologies available in the databank that will benefit industry in the Tri-parish area include hydrogen extraction from seawater, methane hydrate processing, carbon sequestration, extremely high pressure valves and seals, sensors and monitoring systems and advanced power sources for marine application. Workshops and digital online streaming video are also planned.

"This is a great opportunity for industry, both current and future, in South Louisiana," expresses Jane Arnette, executive director for SCIA. "The available technology transfers are a perfect way to enhance economic development for the area. SCIA is pleased it can assist Nicholls with distributing this information through our membership, industrial coalition group and our website."

TECHNOLOGIES continued on page $4 B$

\section{TECHNOLOGIES continued from page $1 B$}

Griffen says he's thrilled to have the opportunity to improve the maritime and offshore industries through Nicholls. He also realizes universities and industrial organizations rarely collaborate on programs like this one.

"If even one business in the Tri-parish area can find a technology that will help it grow, then this project will be a success," Griffen says. "I think it will be a tremendous success for a long time."

Kenny Boudreaux can be reached at (985) 876-3008 or kenny@tri-parishtimes.com. 
South Central Industrial Association

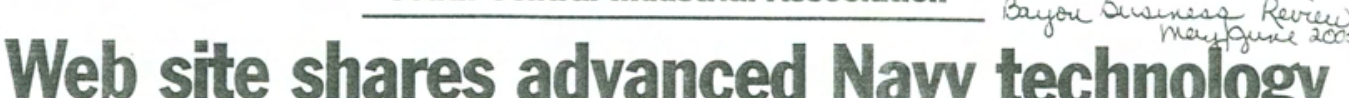

HOUMA - For the past six tries have access to advanced techmonths, SCIA members have nologies that previously have been worked diligently with Nicholls State available only to the U.S. Navy and University professors to develop a its contracted partners.

method to distribute infor-

mation to industrial business-

es on the newly declassifice

U.S. Navy technologies. It is

unique relationship with a

university and an industrial

business organization. This is

a huge opportunity for south

Loulsiana to expand its eco-

nomic development hori

The Shared Technolog

NSU project is to establish

collaborative process with

local industry tor the purpose

of sharing U.S. Navy-devel.

oped technology and to edu.

cate private sector businesses

by increasing awareness of

the avallable vast technology

resources developed with tax-

More than 600 U.S. Nav

Transfer Program is a $\$ 1 \mathrm{mi}$.

patents are available for tech-

lion grant from the U.S. Department nology transter that are available to

of Energy in cooperation with the the public via Web sites, electronic

Advanced Research Center. inserts. SCIA serves an the resource

Through this program, local indus- center to distribute the technology

\section{Sharing technology}

Accessing naval technology is relatively simple by visiting is available to industry in the following areas:

- Acoustics

Composite materials.

- Deep ocean mooring/lifting

- Electrical wet connectors for cables and fiber.

transter information to businesses. People mav access the intormation at the new SCLA Web site, which is wwyy.sciaonline.net, SITTA - technologies. SITTA represents "Share
- Hydrogen - general.

- Mechanical seals and valves.

- Metallurgy and metal joining

methods.

- Risked-based systems engi-

neering.

- Structural fatigue-induced

cracking.

- Technology assessment tech-

niques/processes.

- Vortex-induced vibration.

-Wireless communications.

Alliance.

Once the Web site is accessed, the viewer is given an explanation of the program and directed to the Houston center's site, which explain SEE SCIA, PAGE 9

$30 ! 4$

Continued from Page 8

the various avalable technolugics. thout 20 technologies are being dertionith the hist being updated as available.

John Griffin, an associate professo of petroleum services at $\mathrm{NSU}$ is the principal investigator for SITTA and NSU Bollinger End who holds the Entrepreninger Endowed Chair in Entrepre-neurship in the College of Business, is the eo principal in est. gitor. Though $N$ A $S_{A}$ h has done sim. har programs before, this is the first offish is focused on maritime and offshore industries. Griffin and Byant are working on the project to assist smatler businesses in south Louisiana with exposure to the avail. SCIt's bonges of

SClA's board of directors believes this is a huge opportunity for area busineses to expand anto new tech. ougses. seta pepresents abour 200 esineses with ater 30.000 empioy.

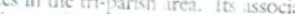
tion with other area industrial groups grcath expands the number of businesses and its resources to 16out 100,000 people.

Through this nerworking source. seta is hopetul many industrial businesses will take adyantage of the technology transfers that are being offered through NST

If a business is interested in a more descriptive presentation of the program, representatives may contact the SCIA office at $85 !-2201$.

Jane Arnette, execurive director of the Houma-based South Central the 


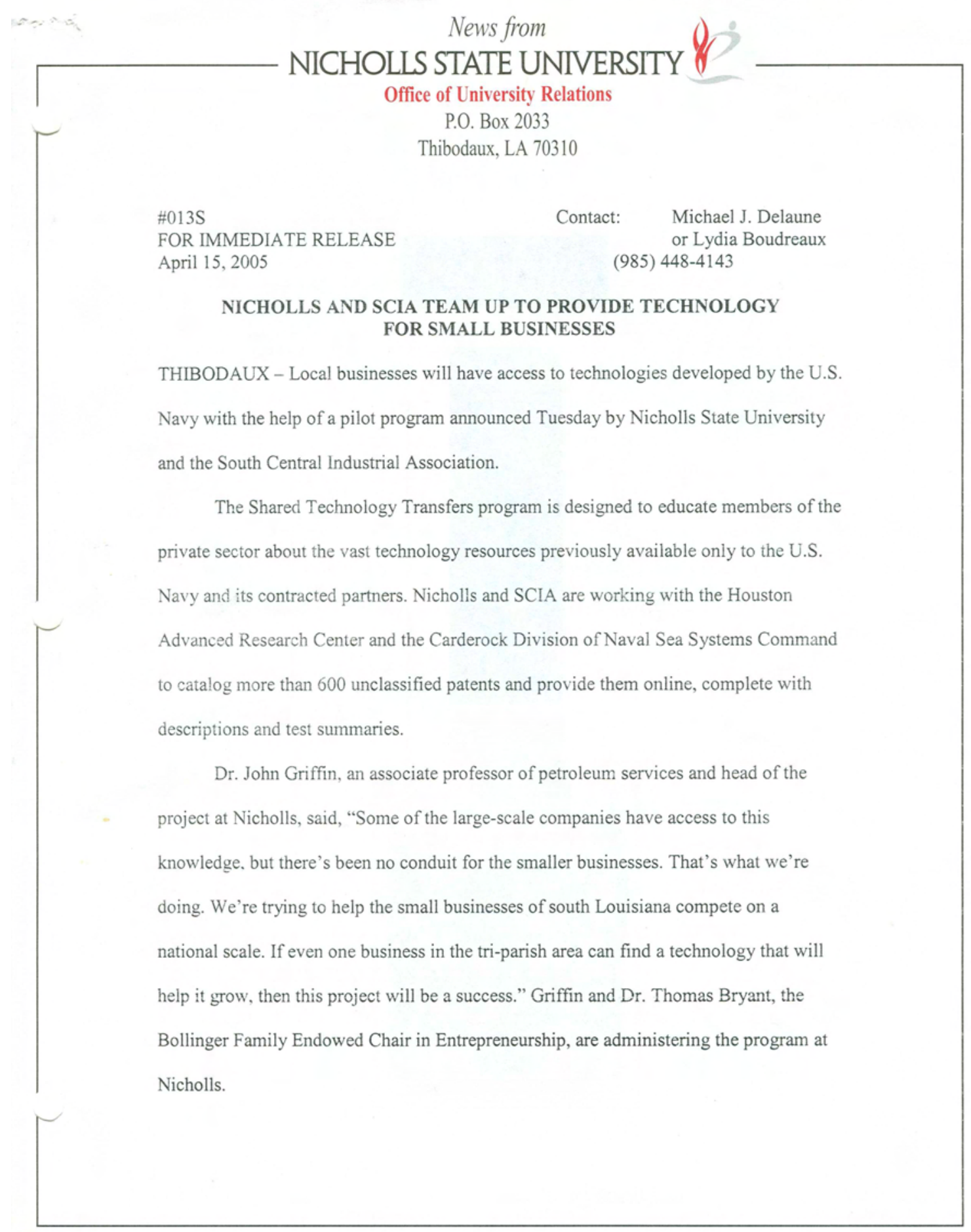


The databank will include technologies for hydrogen extraction from seawater, methane hydrate processing, carbon sequestration, extremely high pressure valves and seals, sensors and monitoring systems and advanced power sources like fuel cells for marine application. SCIA will serve as the resource center to disseminate the information to businesses. Workshops and digital online streaming video are also planned.

SCIA executive director Jane Arnette said, "This is a great opportunity for industry, both current and future, in south Louisiana. The available technology transfers are a perfect way to enhance economic development for the area. SCIA is pleased it can assist Nicholls with distributing this information through our membership, industrial coalition group and our website."

The pilot program is funded by a U.S. Department of Energy grant totaling nearly \$1 million.

For more information about the Shared Technology Transfers program at Nicholls State University, visit www.nicholls.edu/sttp or www.sciaonline.net or call the South Central Industrial Association at (985) 851-2201.

$$
\text { \#\#\# }
$$

Visit the Nicholls State University website at www.nicholls.edu/news to access NSU press releases and photos. 
Appendix I 


34 Catalog

The United States is transitioning to a Hydrogen based economy.

According to the U.S. Department of Energy, currently most hydrogen in the United States, and about half of the world's hydrogen supply, is produced from natural gas. An aggressive research effort is needed that includes new efforts to develop innovative "breakthrough" technologies for extracting fuel-grade hydrogen from natural gas.

\section{Catalog Categories}

Select a category below to view related technologies.

Acoustics
Ceramics
Communications
Composite Materials
Devices
Electric Wet Connectors
Environmental Protection
Fatigue and Crack Growth
Hydrodynamics
Hydrogen Technologies

Logistics

Metallurgy

Mooring and Lifting

Other

Polymers

Safety

Security Systems

Techniques/Processes

Testing

Vortex Induced Vibration

\section{Licensing of Navy Technology}

Government patents are available for licensing. Emphasis is usually placed on the transfer of Naw developed technology to commercial enterprises to strengthen the U.S. industrial base, to create jobs and to secure U.S. suppliers of Naw technology. Click for additional information.

The energy companies of today will be the energy companies of tomorrow.

As the United States transitions to a Hydrogen-based economy, energy companies will continue to seek out open innovation to identify, develop and deploy the technologies required.

\section{Research and development has undergone a dramatic change.}

In the past two decades the methodology for creating value from research knowledge has been fundamentally altered. A value chain links intellectual assets all the way from R\&D to a final product or service. The end product must create economic value for the company that introduces it. Vertical industry structures have given way to horizontal industry structures. Vertical integration, where a single company would conceive, design, manufacture and deliver the product as well as support its customers, has evolved to an open innovation environment. In-house basic research is dying out as a consequence of free flow of ideas, people and products. The government plays a key role in the value chain. In the open-innovation model, success is increasingly based on teamwork, networking and contributing to the activities of others. Industry research relies now on contacts between all researchers, from industry to government to universities and others.

NAVSEA-Carderock, a 3,000 person research organization chartered by Congress to support the domestic maritime industry, is responsible for research and development, testing and evaluation, in-service engineering, logistics, and fleet support of Naw surface and undersea vehicles.

The U.S. Department of Energy has sponsored this catalog of Naw technologies applicable to the hydrogen industry 


\section{Subsea Acoustic Transmission}

Underwater acoustic transmissions use wireless communications to transmit sound signals from undemater sensors. An acoustic modem is used to convert digital data into special underwater sound signals. The signals are then received by a second acoustic modem and converted back into digital data.

The U.S. Naw developed the technology to monitor sub-sea facilities and remote operations. It was designed for use in situations that are too far, too deep, or too unsafe for wires or where wires would interfere with operational activities. Examples of applications for underwater acoustic transmission technology include undemwater telemetry, Remotely Operated Vehicle (ROV) and Automated Undenwater Vehicle (AUV) command and control, diver communications, underwater monitoring, and data logging.

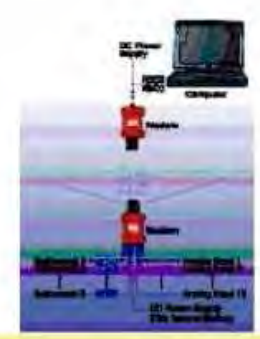

Additional Information

Applications: High speed underwater acoustic modems used for transmitting various data.

TRL: 9 (What is a TRL?) 


\section{What is a TRL?}

TRL stands for technology readiness level

The following paragraphs provide a descriptive discussion of each O\&G technology readiness level, including an example of the type of activities that would characterize each TRL and the cost to achieve.

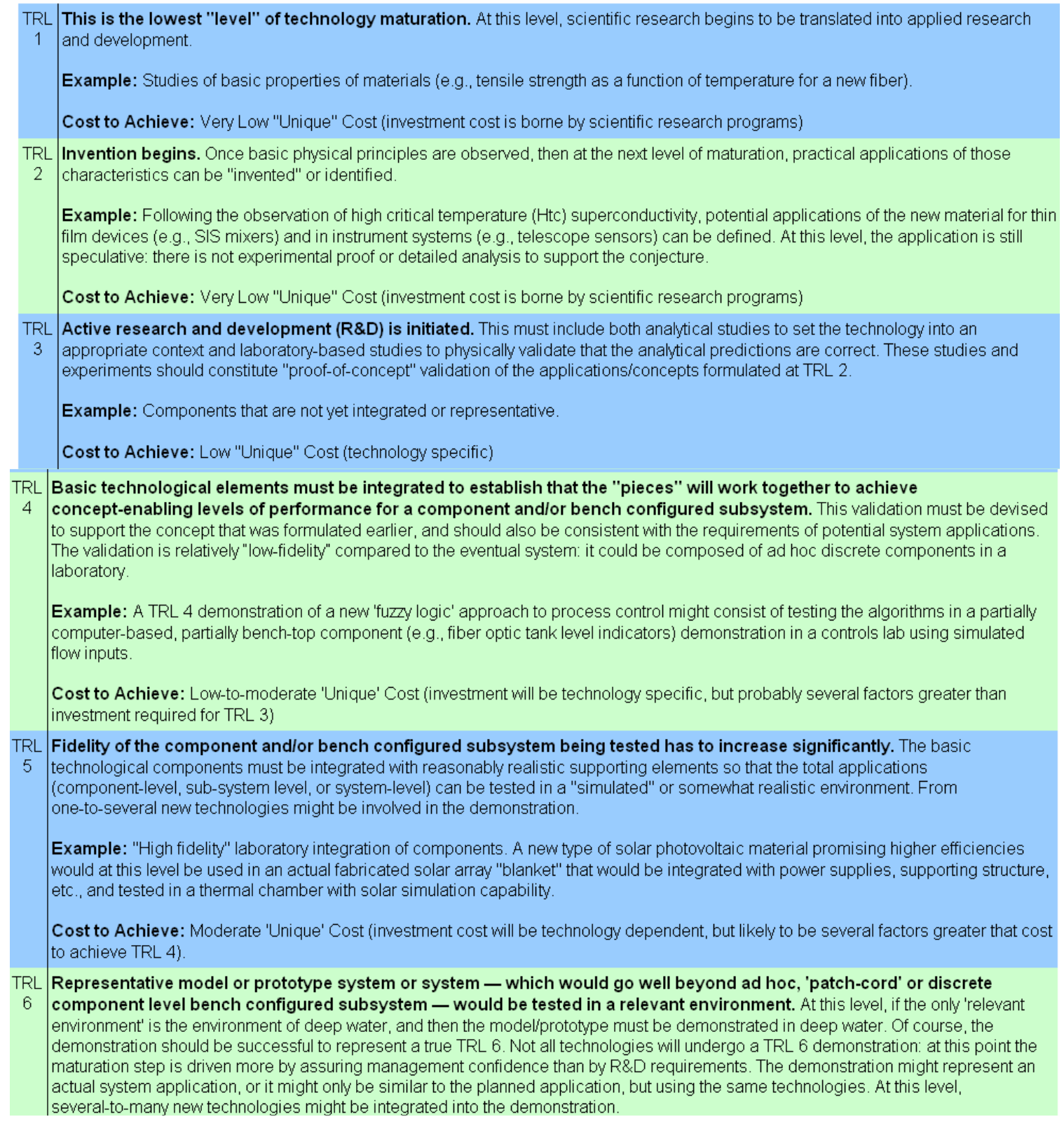


Example: Testing a prototype system or system in a high fidelity laboratory environment or in simulated operational environment. In this example, the reason deep water is the "relevant" environment is that buoyancy plus pressure plus thermal environment effects will dictate the successifailure of the system — and the only way to validate the technology is in deep water.

Cost to Achieve: Technology and demonstration specific; a fraction of TRL 7 if on ground; nearly the same if deep water is required

TRL Prototype near or at planned operational system. Requiring demonstration of an actual system prototype in an operational

7 environment, such as in ROV, or deep water. It has not always been implemented in the past. In this case, the prototype should be near or at the scale of the planned operational system and the demonstration must take place in deep water. The driving purposes for achieving this level of maturity are to assure system engineering and development management confidence (more than for purposes of technology R\&D). Therefore, the demonstration must be of a prototype of that application. Not all technologies in all systems will go to this level. TRL 7 would normally only be performed in cases where the technology and/or subsystem application is mission critical and relatively high risk

Example: Testing the prototype in a test bed ROV

Cost to Achieve: Technology and demonstration specific for demonstration system, but a significant fraction of the cost of TRL 8

TRL Technology has been proven to work in its final form and under expected conditions. In almost all cases, this TRL represents

8 the end of true system development. By definition, all technologies being applied in actual systems go through TRL 8 . In almost all cases, this level is the end of true 'system development' for most technology elements.

Example: Developmental test and evaluation of the system in its intended weapon system to determine if it meets design specifications. Might include integration of new technology into an existing system. Loading and testing successfully a new control algorithm into the subsea computer on downhole system while during drilling operation.

Cost to Achieve: Mission specific; typically highest unique cost for a new technology for actual system

TRL Actual application of the technology in its final form and under mission conditions, such as those encountered in

9 operational test and evaluation. By definition, all technologies being applied in actual systems go through TRL 9 . In almost all cases, the end of last "bug fixing" aspects of true "system development". For example, small fixes/changes to address problems found following launch (through "600 hours" or some related date). This might include integration of new technology into an existing system (such operating a new artificial intelliqence tool into operational mission control). This TRL does not include planned product improvement of

Example: Using the system under operational mission conditions. New turbine for an existing subsea power generator would not start at TRL 9: such "technology" upgrades would start over at the appropriate level in the TRL system.

Cost to Achieve: Mission Specific; less than cost of TRL 8 (e.g., cost of deployment plus 600 hours of mission operations) 